\title{
Pensononowoor
}

2014, vol. 72, 3-27

http://dx.doi.org/10.12657/denbio.072.001

Tomasz P. Wyka, Jacek Oleksyn

\section{Photosynthetic ecophysiology of evergreen leaves in the woody angiosperms - a review}

Received: 18 March 2014; Accepted 20 May 2014

\begin{abstract}
Evergreen plants are an important component of many ecosystems of the world and occur in numerous evolutionary lineages. In this article we review phenotypic traits of evergreen woody angiosperms occurring in habitats that regularly experience frost. Leaf anatomical traits such as sclerenchymatic tissues or prominent cuticles ensure mechanical strength while often enhancing tolerance of water deficit. The low ratio of photosynthetic to nonphotosynthetic tissues as well as modified cell wall structure and nitrogen allocation patterns in evergreen leaves result in lower mass-based photosynthetic rate and photosynthetic nitrogen use efficiency in comparison with deciduous leaves. Their photosynthetic apparatus is adapted for the survival of frost in a down-regulated state with potential for photosynthetic activity in winter during periods of permissive temperatures. Leaf structure interacts with the mechanisms of frost survival. Stem xylem in evergreen plants tends to contain smaller diameter conduits incurring greater resistance to freeze/ thaw induced cavitation than in deciduous plants, although at the cost of reduced hydraulic efficiency. In contrast, no such differences in hydraulic conductivity have been documented at the leaf level. There is evidence for reduced structural plasticity of evergreen leaves in response to variability in irradiance, however photosynthetic downregulation occurs in mature leaves in response to self shading. Some evergreen species exhibit slow leaf development and "delayed greening", while in many species aging is also a very protracted process. Finally, evergreen leaves may participate in carbohydrate and, less obviously, in nitrogen storage for the support of spring shoot and foliage growth, although the importance of this function is under debate. In conclusion, the evergreen leaf habit is correlated with numerous structural and functional traits at the leaf and also at the stem level. These correlations may generate trade-offs that shape the ecological strategies of evergreen plants.
\end{abstract}

Additional key words: internal conductance to $\mathrm{CO}_{2}$, leaf anatomy, sclerophylly, winter photosynthesis, winter photoinhibition.

Addresses: T.P. Wyka, Adam Mickiewicz University, Department of Biology, Institute of Experimental Biology, Laboratory of General Botany, Umultowska 89, 61-614 Poznań, Poland; e-mai: twyka@amu.edu.pl J. Oleksyn, Polish Academy of Sciences, Institute of Dendrology, Parkowa 5, 62-035 Kórnik, Poland, e-mail: oleks001@umn.edu; University of Minnesota, 1530 Cleveland Avenue North, St. Paul, MN 55108 USA

List of Abbreviations: $A_{\max (\text { area) }}$ - photosynthetic rate per unit leaf area $\left(\mu \mathrm{mol} \mathrm{CO} \mathrm{CO}^{-2} \mathrm{~s}^{-1}\right) ; \mathrm{A}_{\max (\operatorname{mass})}$ - photosynthetic rate per unit leaf mass $\left(\mathrm{nmol} \mathrm{CO}_{2}\right.$ $\left.\mathrm{g}^{-1} \mathrm{~s}^{-1}\right) ; \mathrm{g}_{\mathrm{m}}-$ mesophyll $\mathrm{CO}_{2}$ diffusion conductance $\left(\mu \mathrm{mol} \mathrm{CO} \mathrm{m}^{-2} \mathrm{~s}^{-1} \mathrm{~Pa}^{-1}\right)$; LMA - leaf mass per unit leaf area $\left(\mathrm{g} \mathrm{m}^{-2}\right) ; \mathrm{N}_{\text {area }}$ - nitrogen concentration per leaf area $\left(\mathrm{g} \mathrm{N} \mathrm{m}^{-2}\right)$; PNUE - photosynthetic nitrogen-use efficiency $\left(\mu \mathrm{mol} \mathrm{CO} \mathrm{mol} \mathrm{N}^{-1} \mathrm{~s}^{-1}\right)$ 


\section{Introduction}

Leaf life span is a key ecophysiological trait, greatly influencing the photosynthetic capacity, biomass productivity potential, tolerance to biotic and abiotic stresses and role in ecosystem-level interactions of each plant species (Chabot and Hicks 1982; Reich et al. 1992; Kikuzawa and Lechowicz 2011). Even though across the plant kingdom the life span of leaves varies in a continuous manner from weeks to 45 years (Ewers and Schmid 1981; Wright et al. 2004), plant ecologists usually recognize the dichotomy between deciduous vs. evergreen plant habit and treat these as distinct phenological traits. The former group is defined as shedding foliage at the onset of a dormant period, whether caused by drought, cold temperatures or intrinsic growth rhythm and the latter as having no leafless period (Kikuzawa and Lechowicz 2011). The evergreen plant habit is usually achieved through a long leaf life span. However, in Mediterranean-type climates where summers are dry and hot, and winters cool and wet, many species produce successions of short-lived leaves, including ones that function during the winter (Ackerly 2004). In such species, although the life span of individual leaves may be shorter than a single season, because of the production of overlapping leaf cohorts the whole plant is still classified as evergreen (Gratani and Crescente 1997). A number of other variants can be distinguished, blurring the distinction between deciduous and evergreen categories (Kikuzawa and Lechowicz 2011). A recent analysis has indicated, however, that, since leaf life span differentiated the two habits in over $90 \%$ of cases, they should be considered as representing two viable, alternative strategies (van Ommen Kloeke et al. 2012).

Leaf habit is a species-specific trait. Instances when a single species contains genetically determined deciduous and evergreen variants are rare, although climatic factors, especially low temperatures, may prevent or reduce green leaf retention over the winter in genetically evergreen plants. Within the evergreen plant group, however, there is a considerable intraspecific variability in leaf life span. In several species of European dwarf evergreen shrubs leaf life span was longer at higher latitudes (Karlsson 1992). Few studies have addressed the proximal causes of this variability, however, based on common garden results for Pinus sylvestris and Picea abies, it may be mainly environmentally controlled (Reich et al. 1996). Leaf life span may be extended or shortened by shade, depending on circumstances of the entire plant. When the whole plant is shaded, individual leaves live longer than in full sun (Nilsen 1986; Katahata et al. 2007; Yasumura and Ishida 2010), whereas when part of the shoot or crown is well illuminated, the lowermost, shaded leaves frequently undergo ab- scission earlier than the leaves receiving full sun (Kikuzawa and Lechowicz 2011). Leaf life span may be shortened in plants growing on nitrogen-poor soils (e.g. by 3.5 months in Rhododendron ferrugineum; Marty et al. 2009) as the onset of leaf abscission may be induced by the demand for nitrogen from growing parts (Ono et al. 2001; Oleksyn et al. 2003; Marty et al. 2009). In intraspecific and biogeographic analyses, evergreen habit and extended life span are associated with poor nutrient availability (Monk 1966; Givnish 2002; Wright et al. 2002) and low temperature (Reich et al. 2003, 2014; van Ommen Kloeke et al. 2012). Evergreen habit is thus an adaptive trait in many environments. Its consequences may occur at leaf, shoot and whole plant levels and may be environment-specific (Givnish 2002).

Understanding the selective advantages and disadvantages of different leaf habits and variation in leaf life span has been the objective of numerous ecophysiological and biogeographical studies and reviews (e.g. Monk 1966; Chabot and Hicks 1982; Reich et al. 1992; Aerts 1995; Givnish 2002; Kikuzawa and Lechowicz 2011; van Ommen Kloeke et al. 2012). The consensus view is that an extended life span ensures a greater total photosynthetic carbon gain for the amount of nutrients invested in construction of the leaf in comparison to short-lived leaves (Chabot and Hicks 1982). The purpose of this article is to provide an overview of the current issues in ecophysiology of photosynthetic carbon gain by evergreen leaves with emphasis on links between morpho-anatomical and functional characteristics of leaves (and, where relevant, also stems) of evergreen plants, and tradeoffs that result from the evergreen leaf habit. With the vast number of evergreen species worldwide, we focus on species from the temperate and Mediterranean climatic zones and preferably use examples of plants that regularly endure temperatures below freezing. The taxonomic coverage has been limited to angiosperms except where only gymnosperm data were available. We first review the functional interpretations of structural features of evergreen leaves. Next, we examine the relationships between leaf structure and photosynthesis in evergreen and deciduous species and discuss photosynthetic adaptations to winter conditions. Finally, we focus on some less well known functional aspects of the evergreen leaf habit such as rate of leaf development, leaf plasticity and specialization for resource storage.

\section{Anatomy and morphology}

Structural differences between evergreen and deciduous leaves can be quantified using leaf mass per area (LMA, $\mathrm{g} \mathrm{m}^{-2}$ ), a parameter that in interspecific comparisons covaries with leaf life span (Nardini 

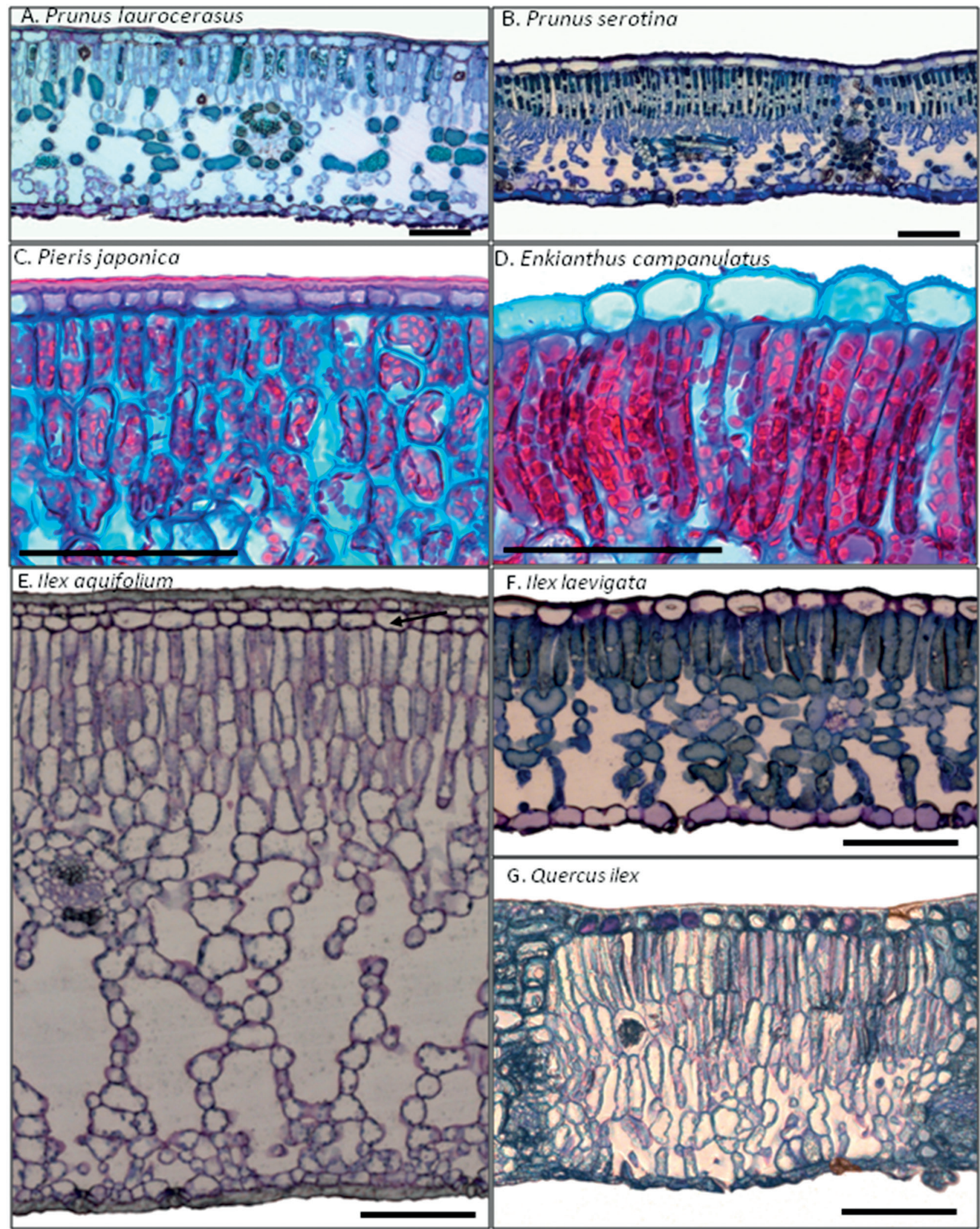

\section{F. llex laevigata}

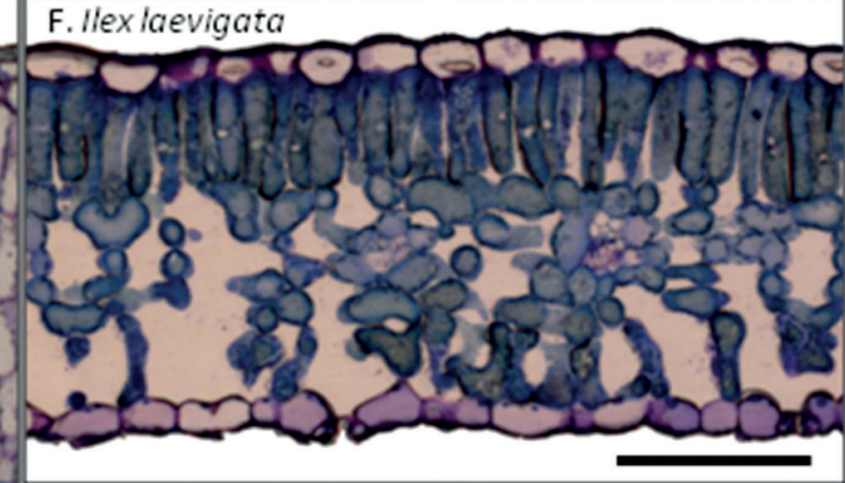

Guercusilex

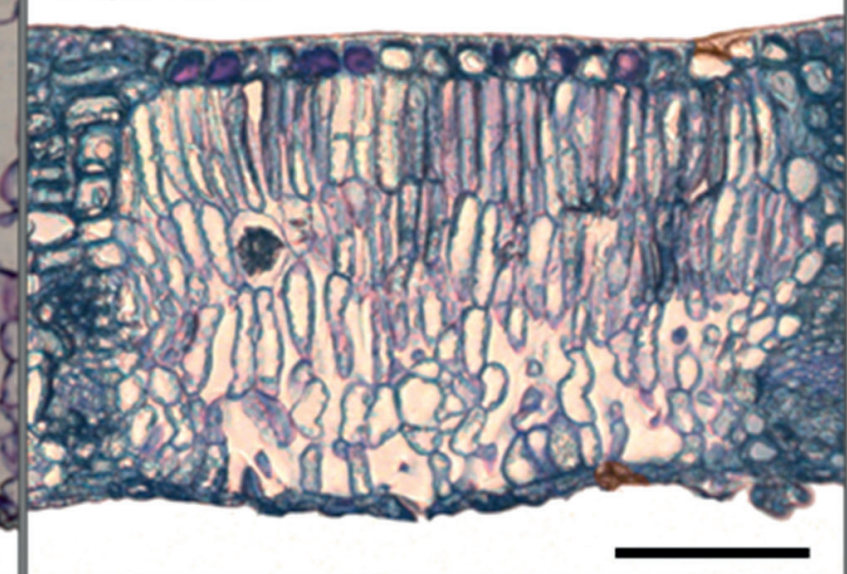

Fig. 1 Cross-sections through evergreen (A, C, E) and deciduous (B, D, F) leaves, belonging to pairs of related species (A, B - Rosaceae;. C, D - Ericaceae; E, F - Aquifoliaceae). An evergreen leaf of Quercus ilex (G - Fagaceae) is also shown. Note features of evergreen leaves: greater lamina thickness (A, E vs. B, F), greater cuticle thickness (C, E vs. D, F), the presence of a collenchymatous hypodermal layer in $\mathrm{E}$ (arrow) and the densely packed mesophyll in G. Also note the abundance of air spaces in spongy mesophyll in A, E. Sections A, B, E, F were prepared in Technovit resin and stained with toluidine blue and sections $\mathrm{C}, \mathrm{D}$ were prepared in paraffin and stained with fast green and safranin. Adaxial indumentum was present in $\mathrm{G}$ but was destroyed during section processing. Bars indicate $100 \mu \mathrm{m}$ 
2001; Reich et al. 1992). LMA is an important leaf attribute depicting a compromise between the capture of light and $\mathrm{CO}_{2}$ fixation, and the limitations imposed by leaf structure, resistance to herbivores and pathogens, and the mitigation of water loss (Sefton et al. 2002). Higher LMA of evergreen leaves may be caused by their greater thickness, but also by greater tissue density (Witkowski and Lamont 1991). The density of leaf lamina is influenced by the packing of cells and by the thickness and composition of the cell walls and, to a lesser extent, by the composition of the protoplasts. Evergreen leaves tend to be both thicker and denser than deciduous leaves (Mediavilla et al. 2001; Mediavilla et al. 2008; Poorter et al. 2009; see Fig. 1 A vs. B, E vs. F) with much interspecific variability (Rotondi et al. 2003; Villar et al. 2013). Studying pairs of closely related evergreen and deciduous species, Villar et al. (2013) concluded that the higher LMA of evergreen leaves is attributable primarily to their greater volume of mesophyll tissue per leaf area, with leaf thickness $60 \%$ higher but leaf density only $10 \%$ higher than in the deciduous species group. Within each leaf type, however, higher LMA is explained by a higher tissue density, due to higher volumetric fractions of mesophyll and lower fractions of air spaces and epidermis.

\section{Mechanical properties}

Anatomical design of evergreen leaves is responsible for their mechanical endurance, rendering them less attractive to herbivores and resistant to physical hazards (Wright and Cannon 2001). Leaf mechanical properties have been shown to depend on LMA (e.g. see data from Kitajima et al. (2012) plotted in Fig. 2 A, B, C). In a global multispecies leaf sample, LMA was a strong predictor of forces needed to shear, punch and tear leaves (Onoda et al. 2011). Much variability of mechanical properties was, however, not explained by bulk LMA indicating that structural reinforcement may result from finer anatomical features.

One extreme of structural leaf variability is represented by sclerophyllous ("hard leaved") species. Measurements of several mechanical characteristics in a range of leaves differing in the degree of sclerophylly have clearly showed that this trait is correlated with mechanical strength and flexural stiffness (Read and Sanson 2003). In typical sclerophyllous leaves mesophyll is densely packed (Fig. 1G), palisade parenchyma is well developed and multilayered, epidermis is thick-walled and covered with a thick cuticle (Fig. $1 \mathrm{C}$ vs. D, E vs. F), and various types of sclerenchymatic tissues are prominent (Rotondi et al. 2003; Jordan et al. 2005). Sclerenchyma fibers may be associated with the midrib and major veins, in some species forming bundle extensions that di- vide the leaf into self-contained sectors (heterobaric leaves). Fibers may also occur as a hypodermal layer or form a bundle along the edge of the lamina as in Buxus sempervirens (Gostin and Ivanescu 2008) and Vaccinium vitis-idaea (Piwczyński et al. 2013). Remarkably diverse arrangements of sclerenchyma fibers are found in various species of Proteaceae (Jordan et al. $2005,2013)$. Another category of sclerenchymatic tissue are various sclereids, developing as idioblasts throughout the mesophyll (Fahn and Cutler 1992; Jordan et al. 2005, 2013.

Many evergreen species, especially those from mesic habitats, lack the abundant sclerenchyma component and instead depend on a tough epidermis, subepidermal collenchyma (Fig. 1 E) and/or cuticular layer for structural reinforcement (Fig.1 C,E; Balsamo et al. 2003). An investigation of mechanical properties of isolated foliar cuticles of 13 Australian evergreen species has shown that cuticle thickness was correlated with resistance to tearing and that tensile strength and modulus of elasticity were much higher than those of leaf laminas (Onoda et al. 2012). Intracuticular wax has been shown to increase the stiffness of Hedera helix and Ilex aquifolium leaves (Khanal et al. 2013).

Leaf toughness is also increased by greater tissue density per se through an increased concentration of wall cellulose in a unit of leaf volume (Onoda et al. 2011; Kitajima et al. 2012). Other wall fractions such as hemicellulose and lignin did not significantly influence toughness as measured in the latter study, however lignin is known to enhance bending resistance - another aspect of leaf mechanical resistance (Alvarez-Clare and Kitajima 2007). Bending resistance and other leaf mechanical traits are also increased by the greater thickness of the lamina, independently of its density (Onoda et al. 2011; see also Fig. 2 D, E, F for data from Kitajima et al. 2012).

\section{Xeromorphism}

While mechanical design of the leaf is an exciting and promising subject of botanical research, anatomical features providing mechanical reinforcement may be multifunctional, with sclerophylly often considered to be primarily a xeromorphic feature as suggested by its prevalence in Mediterranean-type environments (Turner 1994). Mechanical and hydraulic properties of evergreen leaves are closely related. First, the vein network used for water transport contributes to structural strengthening of the leaf, because of the presence of sclerenchymatic sheaths and extensions around the bundles and because of rigid cell walls of the xylem conduits. Second, properties of the extra-xylary pathway of water transport to transpiring surfaces may be influenced by the lignification of mesophyll cell walls 


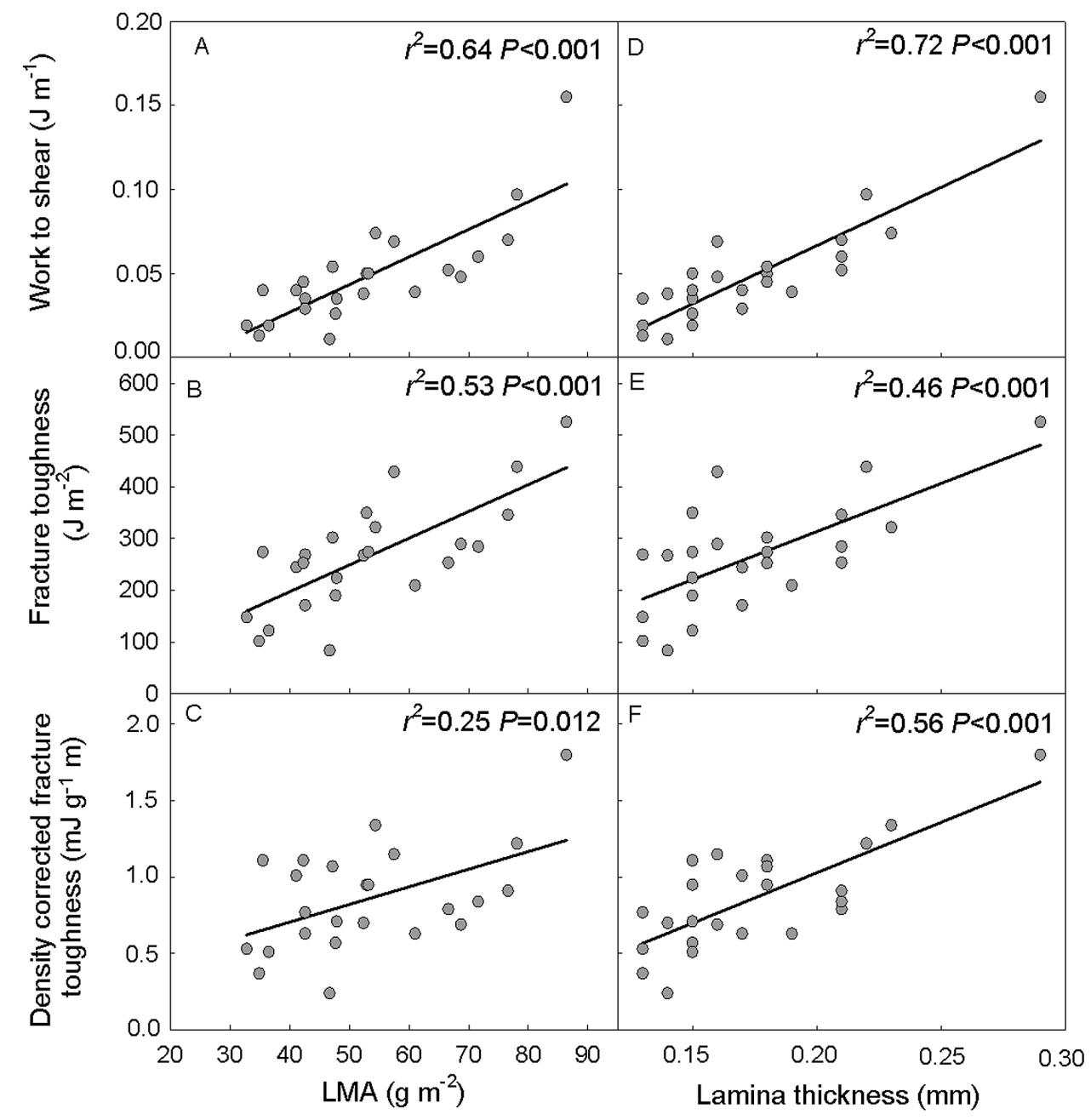

Fig. 2. Dependence of mechanical properties of leaf laminae (work to shear - A, B; fracture toughness - C, D; density corrected fracture toughness - E, F) on leaf mass per area (LMA; A, C, E) and lamina thickness (B, D, F) in seedlings of 24 neotropical tree species. Data are from Table 3 of Kitajima et al. 2013. Determination coefficients $r^{2}$ and associated $t$ values are shown

(increasing their resistance to water movement) and by the high ratio of mesophyll surface area to leaf area in the thickened or dense leaves (Zwieniecki et al. 2007; Simonin et al. 2012). Integrated properties of individual components of the water transport pathway determine the hydraulic conductance of the whole leaf.

Thickening and secondary modifications of the cell walls increase their elastic modulus, i.e. make the cells more rigid. Bulk elastic modulus in three tropical evergreen species averaged $15 \mathrm{MPa}$, comparing to $10 \mathrm{MPa}$ in three deciduous species (Sobrado 1986) and was $22 \mathrm{MPa}$ in the evergreen Heteromeles arbutifolia compared with $17 \mathrm{MPa}$ in the deciduous Prunus serrulata (Balsamo et al. 2003). On dehydration, the rigid cells of evergreen leaves undergo smaller volume change for a similar amount of turgor drop compared to cells of deciduous leaves (Sobrado 1986; Salleo and Lo Gullo 1990; Salleo et al. 1997). Leaves of two sclerophyllous evergreens
Viburnum tinus and Ilex aquifolium lost turgor after losing only $13 \%$ of water compared with deciduous Sambucus nigra and a soft-leaved evergreen Hedera helix, that both lost turgor after losing over $20 \%$ of water (Salleo et al. 1997). Thus, the less elastic mesophyll of evergreen leaves also stores relatively less water available for withdrawal without losing turgor. However, such rigid cells may tolerate lower water potentials, facilitating water uptake from the drying soil without suffering damage to the photosynthetic apparatus that might be caused by major cell volume changes (Lo Gullo and Salleo 1988; Turner 1994). Their mechanical tissues provide an additional protection from distortion of the leaf structure allowing for an easier recovery from dehydration. Scleromorphic leaves may also be adaptive in high light environments, with hypodermal fibers and thick cuticle increasing the tolerance to high irradiance (e.g. in the Proteaceae; Jordan et al. 2005). 


\section{Construction costs}

The abundance of strengthening features in evergreen leaves suggests a high cost of leaf construction. Chemical analyses of evergreen leaves usually yield higher cellulose and hemicellulose concentrations, and, often but not always, a higher lignin concentration compared to deciduous species (Villar and Merino 2001; Mediavilla et al. 2008). The metabolic cost per unit of leaf biomass has been estimated by measuring the heat of combustion corrected for ash content and additionally calculating the cost of protein synthesis (Villar and Merino 2001). The average cost of construction of evergreen leaves from diverse ecosystems was $1.55 \mathrm{~g}$ glucose $\mathrm{g}^{-1}$, i.e. $6 \%$ higher than the construction cost of deciduous leaves $\left(1.46 \mathrm{~g}_{\text {glucose }} \mathrm{g}^{-1}\right)$. Leaves of evergreen species had a higher heat of combustion, and lower nitrogen and ash concentration, however these costs were reduced by the lower contribution of protein synthesis to construction costs ( $16 \%$ vs. $26 \%$ in deciduous species). Lignin, phenolic and lipid concentrations contributed especially strongly to construction costs (Villar and Merino 2001). The costs are high especially where the cuticle is very thick (in some cases accounting for up to $24 \%$ of lamina dry mass), because its main component (cutin) is over two times more costly to synthesize than carbohydrates (Onoda et al. 2012). Variability in leaf chemical composition and construction costs, however, has a significant phylogenetic component, with leaf habit explaining only a minor fraction (Villar et al. 2006). When expressed on the basis of projected leaf area, the difference in construction costs is much larger than on the basis of leaf mass, [e.g. 237 vs. 130 g glucose $\mathrm{m}^{-2}$ in, respectively, evergreen and deciduous species studied by Villar and Merino (2001)], because of the multiplicative effect of greater LMA and a higher cost of leaf biomass in evergreen species.

Calculation of construction costs allows estimation of the energy investment in leaves, but does not fully reflect integrated lifetime costs that, in addition to costs of synthesis of leaf dry matter, should also include respiratory costs. At present there is not enough information to compute a complete lifetime energy budget of evergreen vs. deciduous leaves, however respiration per dry mass in evergreen leaves is lower than that in deciduous leaves under both dark and light conditions (Villar et al. 1995; Reich et al. 1998a; Tjoelker et al. 1999; Wright et al. 2005a). This slower respiration is related to lower $\mathrm{N}$ concentration as an index of leaf metabolic activity (Reich et al. 1998a), however for a given $\mathrm{N}$ concentration evergreen leaves still respire more slowly than deciduous leaves (Wright et al. 2005a).

\section{Photosynthetic rates}

A large number of studies have addressed the consequences of the evergreen leaf habit for photosynthetic capacity at various time scales and under different environmental conditions. According to the global meta-analyses published by Reich et al. (1997; 1998a), Wright et al. (2004; 2005a, b) and many individual studies (e.g. Hassiotou et al. 2009, 2010; Hikosaka and Shigeno 2009), photosynthetic rate expressed per leaf mass $\left(\mathrm{A}_{\max (\operatorname{mass})}\right)$ is negatively correlated with LMA, i.e. the thicker or denser the leaf, the lower its mass-based photosynthetic rate. Because of the strong coupling of leaf longevity with LMA (Reich et al. 1992; Wright et al. 2005b), evergreen leaves as a group have lower $\mathrm{A}_{\max (\operatorname{mass})}$ than deciduous leaves (Reich et al. 1998a,b; Hikosaka and Hirose 2000; Wright et al. 2005a). On a leaf area basis this relationship is less straightforward because, on the one hand, the greater amount of photosynthetic tissue per unit leaf area results in a higher $\mathrm{A}_{\max (\text { area) }}$ and on the other hand, anatomical modifications associated with increased LMA may lead to the lowering of $\mathrm{A}_{\max (\text { mass })}$ (see below), with the net effect on $\mathrm{A}_{\max (\text { area) }}$ dependent on the relative strength of these opposing effects. Globally, however, evergreen leaves have lower $\mathrm{A}_{\text {max (area) }}$ than deciduous species (Reich et al. 1998a; Wright et al. 2005a).

The lower $A_{\max (\operatorname{mass}}$ in evergreen leaves is thought to be largely caused by the "dilution" of photosynthetic tissues due to the abundance of structural elements (Harrison et al. 2009). This dilution effect leads to a lower leaf concentration of nitrogen, a nutrient principally involved in photosynthetic functions and a strong predictor of photosynthetic capacity (Field and Mooney 1986). However, photosynthetic rate expressed per unit of foliar nitrogen (known as instantaneous photosynthetic nitrogen use efficiency, PNUE) is usually also lower in evergreen than in deciduous species (Reich et al. 1998a; Takashima et al. 2004; Warren and Adams 2004; Juárez-López et al. 2008) but see Hikosaka and Hirose (2000). Several hypotheses have been proposed to explain this difference in PNUE, emphasizing the role of leaf structure (hypotheses 1 and 2 below) or nitrogen allocation pattern (hypotheses 3 and 4).

\section{Hypothesis (1)}

Structural characteristics of the high-LMA evergreen leaf may cause lower conductance to $\mathrm{CO}_{2}$ transfer between the sub-stomatal cavity and chloroplasts $\left(g_{m}\right)$, leading to lower availability of $\mathrm{CO}_{2}$ at rubisco carboxylation sites (Field and Mooney 1986). Measurements of $g_{m}$ using online discrimination against ${ }^{13} \mathrm{CO}_{2}$ or combined gas exchange and fluorescence techniques in connection with photosyn- 
thetic modeling have so far allowed estimation of $g_{m}$ in over 100 species including numerous evergreens (Niinemets et al. 2009a,b; Hassiotou et al. 2010). In agreement with this hypothesis, $g_{m}$ in four species of evergreen fruit trees was lower than in the deciduous peach (Syvertsen et al. 1995; Marchi et al. 2008) and in a set of 35 species of Australian sclerophylls $g_{m}$ was negatively correlated with both LMA and leaf longevity (Niinemets et al. 2009a). A similar finding was reported for seven species of sclerophyllous Banksia (Hassiotou et al. 2009) and in a literature-derived data set of 81 diverse species including many evergreens (Niinemets et al. 2009b). As an exception, leaves of an evergreen and a deciduous Quercus species had similar $g_{m}$ (Mediavilla et al. 2002).

The generally low $g_{m}$ in evergreen or sclerophyllous leaves might be potentially attributed to resistances in both the gas (intercellular spaces) and the liquid (cell wall to chloroplast stroma) phase (Syvertsen et al. 1995). The denser packing of cells and greater mesophyll thickness cause a greater tortuosity of the diffusion pathway. However, because of the large diffusion coefficient of $\mathrm{CO}_{2}$ in the gas phase relative to the liquid phase, the influence of gas phase conductance on total mesophyll conductance is not major except in very dense mesophyll (Terashima et al. 2006). Consequently, the relationship between mesophyll porosity and $g_{m}$ is ambiguous and varies from positive (Loreto et al. 1992; Syvertsen et al. 1995) to negative (Hanba et al. 1999). In contrast, mesophyll cell walls constitute the major diffusional resistance estimated at $50 \%$ of total mesophyll resistance for herbaceous leaves and potentially more in leaves with thicker cell walls (Terashima et al. 2011). For a group of 32 sclerophyllous taxa the contribution of cell wall resistance to total mesophyll resistance was estimated to be between 50 and $70 \%$ and was correlated with cell wall thickness (Tosens et al. 2012). In an evergreen Quercus, mesophyll cell walls were indeed thicker than in a deciduous congeneric species (Terashima et al. 1995), similarly to five evergreen vs. five deciduous woody species from diverse families (Tomás et al. 2013). Although simultaneous measurements of cell wall thickness and $g_{m}$ are sparse, in three multi-species studies cell wall thickness appeared to be positively correlated with LMA and negatively with $g_{m}$ (Hassiotou et al. 2010; Tosens et al. 2012; Tomás et al. 2013). Moreover, the porosity of mesophyll cell walls is expected to be lower in evergreen leaves because of their potentially greater lignification, thus further restricting $g_{m}$ (Tosens et al. 2012). Furthermore, perennial evergreen leaves undergo extensive secondary age- and stress- induced changes in their mesophyll wall structure, including thickening and hardening, that lead to a decrease in $g_{m}$ and restriction of photosynthetic capacity (Karlsson 1985; Niinemets et al. 2005).
Having crossed the cell wall, $\mathrm{CO}_{2}$ diffuses to rubisco carboxylation sites also in the liquid phase, including plasma membrane, cytoplasm, chloroplast envelope and stroma. Shortening of this pathway greatly increases $g_{m}$ and, on a leaf area basis, may be achieved by increasing the surface area of chloroplasts adjacent to intercellular air spaces (Terashima et al. 2006; Terashima et al. 2011). The thick laminas of evergreen leaves provide additional mesophyll cell wall area available for chloroplast packaging, thus potentially compensating for thicker cell walls (Hanba et al. 1999). However, where walls are very thick the additional impact of chloroplast distribution on $g_{m}$ may be negligible (Tomás et al. 2013). Remarkably, species with thick cell walls had thinner chloroplasts, suggesting that they have been subjected to selection pressure to optimize anatomical requirements of long leaf life span and efficient photosynthesis (Tosens et al. 2012). Regardless of which specific structural features contribute to restricting $g_{m}$, chloroplasts in evergreen leaves function under lower $\mathrm{CO}_{2}$ concentrations and experience a greater degree of limitation of photosynthesis by mesophyll conductance relative to deciduous species (Niinemets et al. 2009a,b). With the progressing understanding of the rapid modulation of $g_{m}$ due to changes in activity of carbonic anhydrase and water channels, further work is required to partition the controls of $g_{m}$ between structural and physiological factors in the context of leaf form and longevity (Evans et al. 2009).

\section{Hypothesis (2)}

Evergreen leaves may be less efficient than deciduous leaves at ensuring penetration of light down the mesophyll profile, leading to reduced photosynthetic rates in the abaxial mesophyll layers. Light attenuation in the leaf profile is influenced by anatomical structure (Vogelmann 1993; Terashima and Hikosaka 1995). Species of Eucalyptus with multilayered palisade mesophyll contained more chlorophyll per leaf area than species with thin palisade, but light absorptance was similar, yielding reduced efficiency of light capture per unit chlorophyll (Sefton et al. 2002) and probably increasing shading of the abaxially located cells. Leaves illuminated at a saturating level from the adaxial direction will often increase photosynthesis if additional light is also provided from abaxial side, suggesting that chloroplasts in the abaxial mesophyll are normally undersaturated (Evans et al. 1993). When deciduous angiosperm and evergreen gymnosperm leaves were subjected to bilateral illumination, photosynthesis increased relative to measurements with adaxial illumination only, and magnitude of the increase was positively correlated with LMA, confirming greater mesophyll self-shading in high-LMA evergreen leaves (Green and Kruger 
2001). Certainly the prominent development of cuticle and the abundance of mechanical tissues would further decrease the efficiency of light utilization in evergreen leaves, although certain types of sclereids may help to guide light into the deep mesophyll as shown in Phillyrea latifolia (Karabourniotis 1998).

\section{Hypothesis (3)}

It has been proposed that nitrogen partitioning to non-photosynthetic functions, such as structural wall proteins, $\mathrm{N}$-intensive defensive compounds and other compounds increasing longevity, may be greater in evergreen than in deciduous leaves (Field and Mooney 1986; Warren and Adams 2004). In agreement with this hypothesis, two evergreen species of Quercus allocated greater fractions of nitrogen to detergent insoluble (i.e. wall) proteins in comparison to two deciduous species, suggesting a tradeoff between leaf habit and PNUE (Takashima et al. 2004). This result, however, has not been validated for other species. When a diverse sample of only evergreen species was analyzed, LMA was not correlated with the wall nitrogen fraction (Harrison et al. 2009). The fraction of nitrogen allocated to rubisco, on the other hand, has been shown to decline with LMA in some studies (Ellsworth et al. 2004; Harrison et al. 2009; Hikosaka and Shigeno 2009), while in Australian sclerophylls it was highly variable and was not lower than in other, more mesophyllic C3 species (Warren et al. 2000). In contrast to metabolism-associated proteins, the concentration of wall proteins does not decrease with leaf age because the insoluble wall proteins are resistant to degradation and undergo hardly any resorption. Their fraction therefore increases, contributing to the age-related decline in PNUE (Yasumura and Ishida 2010). Thus, at least in aging evergreen leaves, the low PNUE may be partially attributed to low relative allocation of $\mathrm{N}$ to rubisco, whereas the trade-off between photosynthetic and wall nitrogen is questionable in fully active leaves. More measurements are certainly needed to strengthen this finding.

\section{Hypothesis (4)}

Some of the rubisco present in evergreen leaves may not be active in carboxylation, instead playing the role of a storage molecule as suggested by the presence of excessive amounts of this enzyme in relation to actual $\mathrm{CO}_{2}$ uptake rate (Warren et al. 2000; Warren and Adams 2004). A study of 8 species of co-occurring evergreen forest trees in Japan, however, found no connection between leaf life span $(0.5$ to 2 years) and photosynthetic rate per unit rubisco (Hikosaka and Hirose 2000). While this hypothesis is still under consideration a case has been reported of rubisco accumulation in expanding chloroplasts of Aucuba japonica prior to winter (Muller et al. 2009). Although the latter authors favored the interpretation of rubisco accumulation as a photosynthetic acclimatory preparation for higher irradiance during winter, the reduced winter activity of rubisco nevertheless suggests a storage function.

Taken together, studies investigating the question of low $\mathrm{A}_{\max (\operatorname{mass})}$ and PNUE in evergreen leaves have produced ample evidence for trade-offs between photosynthetic efficiency and structural and functional requirements of long leaf life span. Such trade-offs are the basis of coexistence of evergreen and deciduous strategies (Chabot and Hicks 1982). To understand the advantages and disadvantages of the evergreen leaf form, integrated lifetime carbon income needs to be weighed against leaf construction and maintenance costs at the leaf and the plant levels (Aerts 1995; Givnish 2002). This complex task has been recently approached by Falster et al. (2012) who, by modeling lifetime carbon gain in leaves of temperate Australian woody plants experiencing progressive self-shading, and correcting it for dark respiration, showed a positive relationship between leaf longevity and life-time carbon return. Under this scenario, evergreen leaves with their lower photosynthetic rate are superior over deciduous leaves in terms of carbon return per unit of resource invested in the leaf, but deciduous species match that output by quickly reinvesting resources into making new, more efficient leaves ("time discounting effect", Falster et al. 2012).

\section{Adaptation of evergreen leaves to winter conditions}

\section{Winter photosynthesis and photoinhibition}

Maintenance of functional leaves through the unfavorable period of low temperatures allows evergreen plants to capitalize on additional windows of photosynthetic opportunities when the potentially competing deciduous species are leafless. However, photosynthetic carbon uptake, as an enzymatic process, is temperature dependent, therefore during cool winters the net $\mathrm{CO}_{2}$ uptake is temperature limited. Additionally, seasonal downregulation of photosynthetic capacity causes a decrease of $\mathrm{CO}_{2}$ uptake rate also during brief periods of potentially permissive temperatures. Winter declines of the capacity for $\mathrm{CO}_{2}$ uptake have been documented e.g. in Hedera helix (Oberhuber and Bauer 1991), Mahonia repens (Logan et al. 1998; but see Adams et al. 2002), Phillyrea angustifolia (Arena et al. 2006), Nerium oleander and Laurus nobilis (Meletiou-Christou and Rhizopoulou 2012). 
This regulated acclimation process occurs in response to the onset of low temperatures and is followed by springtime de-acclimation and photosynthetic recovery (Oberhuber and Bauer 1991; Verhoeven et al. 1998; Neuner et al. 1999; Öquist and Huner 2003). Winter decline of photosynthesis thus results from both environmental and endogenous controls. It may, however, be aggravated by frost damage (Bauer and Kofler 1987).

Although snow cover may protect evergreen leaves from frost damage, low light and near or below zero temperatures under snow prevent photosynthesis. However, when snow cover partly melts allowing access of sufficient light, positive net photosynthesis resumes, as in low-statured arctic evergreen shrubs Vaccinium vitis-idaea, Ledum palustre and Cassiope tetragona (Starr and Oberbauer 2003). In snow covered Vaccinium vitis-idaea photosynthetic capacity dropped to $4 \%$ of annual maximum during the coldest period but recovered to $25 \%$ of maximum before snow melt (Lundell et al. 2008). Also Rhododendron ferrugineum retained substantial photosynthetic capacity under a heavy snowpack (Larcher and Siegwolf 1985). In leaves not covered by snow, winter photosynthetic decline is stronger in leaves exposed to higher irradiance, indicating the prevailing influence of photo-oxidative stress (Oberhuber and Bauer 1991; Logan et al. 1998; Adams et al. 2002).

The mechanism of photosynthetic downregulation involves a synchronous decrease in carboxylation capacity of rubisco and photosynthetic electron transport (Miyazawa and Kikuzawa 2005a; Miyazawa et al. 2007). The downregulation of electron transport capacity is typically measured as a decline in photochemical efficiency of PSII correlated with an enhanced thermal dissipation of absorbed light energy (Adams et al. 2004; Hormaetxe et al. 2007). Such a trend has been reported e.g. for Cistus albidus (Oliveira and Peñuelas 2002), Ilex aquifolium (Groom et al. 1991), Hedera helix (Oberhuber and Bauer 1991), Euonymus kiatchovicus (Verhoeven et al. 1998), Eucalyptus pauciflora (Blennow et al. 1998), Mahonia repens (Logan et al. 1998), Rhododendron catawbiense (Harris et al. 2006), Quercus ilex ssp. ballota (Corcuera et al. 2005) and many other evergreen species. It is accompanied by the accumulation of photoprotective xanthophylls, zeaxanthin and antheraxanthin, and their permanent retention in the de-epoxidized state (Oberhuber and Bauer 1991; Verhoeven et al. 1998; García-Plazaola et al. 2003; Corcuera et al. 2005). The mechanism of sustained winter quenching via de-epoxidized xanthophylls in evergreen leaves is thus distinct from the dynamic engagement of nonphotochemical quenching operating at the scale of minutes to hours in response to excessive irradiance at mild temperatures, and is much less understood (Verhoeven et al. 1998; reviewed in Öquist and Hun- er 2003). The second photoprotective mechanism involves the degradation of D1 protein in the PSII core and proteins of the oxygen-evolving complex, with the resulting inhibition of photosynthetic electron transport (Adams et al. 2004; Zarter et al. 2006).

While nonphotochemical quenching and downregulation of electron transport reduce the formation of reactive oxygen species, further protection of the cellular environment is provided by antioxidative enzymes (Logan et al. 1998) or several categories of antioxidative compounds, some of which, e.g. $\alpha$-tocopherol (García-Plazaola et al. 1999, 2003; Kyparissis et al. 2000), glutathione (Logan et al. 1998) or phenylopropanoids (Grace et al. 1998), have been shown to accumulate during winter. Whole leaves may transiently change color from green to red due to accumulation of carotenoids (e.g. retro-carotenoids in Buxus sempervirens, Hormaetxe et al. 2004) or anthocyanins (Hughes et al. 2012). Red leaf coloration is enhanced by solar radiation and is accompanied by the decrease of the chlorophyll $a / b$ ratio, suggesting a shading effect of pigments on the chloroplasts. Although light screening is the favored explanation for the presence of anthocyanins, their role as antioxidants is also possible (Hughes 2011). A variety of other acclimatory metabolic changes have been described, e.g. estrification of xanthophylls with fatty acids in Buxus sempervirens (Hormaetxe et al. 2004), conversion of chlorophyll into an inactive storage form in Eucalyptus pauciflora (Gilmore and Ball 2000), accumulation of dehydrins (Harris et al. 2006) and early light-induced proteins (ELiPs; Peng et al. 2008b), and downregulation of aquaporins (Peng et al. 2008a) in Rhododendron catawbiense.

In response to low temperature, leaves of some evergreen species perform thermonastic movements, involving reversible lamina drooping and rolling. Examples of thermonastic species include Rhododendron catawbiense (Wang et al. 2008), Rhododendron maximum (Bao and Nilsen 1988), some other evergreen Ericaceae (Russell et al. 2009) and Viburnum rhytidophyllum (Fig. 3). Such change in leaf orientation reduces photooxidative damage by decreasing lamina exposure to light but also protects the leaf from desiccation and allows rapid recovery of photosynthetic activity in the spring (Nilsen 1992; Russell et al. 2009). The benefits of the thermonastic movements occur only in the exposed parts of the crown (Russell et al. 2009). This and other photoprotective mechanisms contribute to the preservation of structural and functional integrity of chloroplasts through the winter when energy loads received by the leaf exceed its capacity for carboxylation.

Much environmentally induced and interspecific variation exists in the employment of the various strategies (Adams et al. 2004). For example, winter downregulation of photochemistry and photo- 


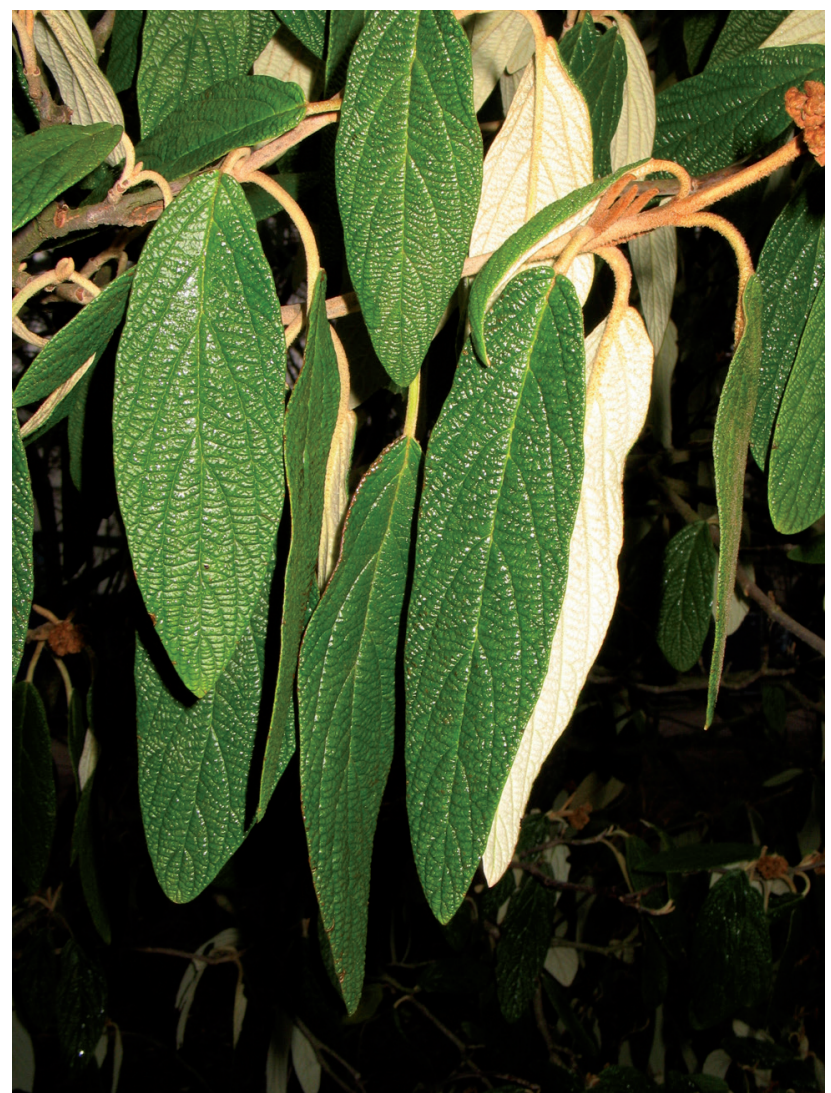

Fig. 3 Evergreen leaves of Viburnum rhytidophyllum in a state of thermonastic drooping during freezing temperature conditions

synthetic $\mathrm{O}_{2}$ evolution in Arctostaphylos uva-ursi was complete at a high mountain site but nearly absent at a low elevation site, reflecting the difference in the harshness of weather conditions (Zarter et al. 2006). It has been hypothesized that variation in the extent of downregulation of photosynthesis may be related to differences in carbohydrate sink activity. While overwintering herbaceous plants often retain the capacity for growth during periods of permissive temperatures and retain or even enhance their photosynthetic capacity, typical woody evergreens cease growth during winter, thus cutting down the utilization of photosynthates and simultaneously downregulating photosynthesis (Adams et al. 2002, 2004). Intermediate behaviors also occur, depending on the activity of sinks other than shoot growth, such as root growth or carbohydrate storage. It has been also suggested that sensitivity of the phloem transport to cold might constrain photosynthetic activity, especially in species with symplastic phloem loading (Adams et al. 2002).

During periods of subfreezing temperatures photosynthesis is inhibited completely, however during warmer periods winter leaves often have significant photosynthetic activity. Where temperature allows, winter $\mathrm{CO}_{2}$ uptake may be an important contribution to the annual $\mathrm{CO}_{2}$ budget, e.g. because of favorable moisture conditions in Mediterranean vegetation (Varone and Gratani 2007) or abundant light in the understory of temperate deciduous forests (Miyazawa and Kikuzawa 2005b). Saplings of six understory evergreen species in central Japan showed an early winter decline and a late winter recovery of photosynthetic capacity, with Camellia japonica and Ilex pedunculosa maintaining as much as ca. $50 \%$ and $25 \%$ of their respective summer capacities even during the coldest period in January (Miyazawa and Kikuzawa 2005b). When integrated over the whole year, assimilation during the 4.5 months of winter in three of these six species exceeded that during the rest of the year, illustrating the advantages of an evergreen life strategy under a deciduous forest canopy.

\section{Structural adaptations for frost tolerance}

Plants with wintergreen leaves occur and sometimes even dominate in environments where frost occurs regularly, including boreal, alpine, and some temperate and Mediterranean areas. Tolerance of winter conditions may be enhanced by some of the structural leaf traits associated with mechanical endurance and xeromorphy that could prevent damage by snow or ice. The thick, wax-rich cuticles protect evergreen leaves from winter desiccation by ensuring a very low cuticular water permeability, while stiffness of the cell walls and whole leaf may slow down dehydration of the protoplasts (Rajashekar and Burke 1996; Burghardt and Riederer 2003). Whereas the physiological mechanisms of cellular low temperature tolerance are beyond the scope of this review (except for photoprotective mechanisms discussed above), their functioning in the leaf may be influenced by the anatomical structure.

Avoidance of freezing damage requires that ice is not formed in the protoplasts. This end may be achieved by two complementary mechanisms: the supercooling effect allowing the protoplasmic (and sometimes, also the apoplastic) water to remain liquid in spite of subzero temperatures and extracellular ice nucleation, whereby water is partly withdrawn from protoplasts into the apoplast where it forms an ice layer on the outer surface of the cell walls or between the wall and the protoplast (Sakai and Larcher 1987; Körner 2003). Leaves of several evergreen species have been found to supercool down to $-10^{\circ} \mathrm{C}$ or $-12^{\circ} \mathrm{C}$ (Sakai and Larcher 1987) and in the evergreen bamboo Sasa senanensis supercooling was effective down to $-22^{\circ} \mathrm{C}$ (Ishikawa 1984). The effectiveness of supercooling appears to be influenced by the internal leaf structure. The preferred anatomical environment for supercooling is provided by leaves with small, densely packed mesophyll cells and small intercellular spaces (Neuner and Bannister 
1995). Sclerenchymatous bundle sheath extensions that divide the air space of the leaf into small compartments further favor the supercooling mechanism by restricting the spreading of ice from its nucleation sites as shown for Nothofagus menziesii (Neuner and Bannister 1995), Sasa senanensis (Ishikawa 1984) and a tropical tree Cinnamomum camphora (Hacker and Neuner 2007). Abundant intercellular spaces, on the other hand, provide space to accommodate extracellular ice (Ball et al. 2004).

The exact sites of initial ice nucleation or pathways of ice propagation have been subject of much discussion and research, typicaly revealing consistent, species specific patterns. For example, anatomical zones for massive ice accumulation have been identified in the midribs of cold-acclimated Eucalyptus pauciflo$r a$ where ice deposits form in intercellular spaces of parenchyma strands located on the upper and lower side of the vascular bundle (Ball et al. 2004). In recent years, the employment of high-resolution infrared differential thermal analysis has allowed to further link leaf anatomy with ice nucleation and propagation pathways in evergreen leaves (Hacker and Neuner 2007; Hacker and Neuner 2008). Whereas in deciduous species ice propagated inside the leaf from the petiole following the venation network, in 1-year old leaves of the evergreen Buxus sempervirens, ice nucleation took place in a lacunar space separating palisade and spongy mesophyll, followed by the formation of a central ice lens. This lacuna was absent from current year leaves in which, accordingly, ice propagated along the vein network. The basis for such ordered patterns of ice formation has not been elucidated but an involvement of anatomical ice propagation barriers, localized presence of heterogenous nucleation agents and antifreeze proteins (AFPs) that adhere to ice crystal surfaces and direct their growth have all been implicated (Wisniewski et al. 2014).

\section{Winter xylem dysfunction}

Maintenance of leaves through periods of subfreezing temperatures in a sufficiently hydrated state is a prerequisite for their further photosynthetic functionality and depends on the safety and efficiency of water transport to the leaf and within the leaf. Exposure to freezing/thawing cycles may disrupt water flow in the xylem by causing conduit cavitation (Zimmermann 1983). A cavitated stem xylem cannot supply water to evergreen leaves, inducing stomatal closure and a reduction of photosynthesis. If cavitation persists, photosynthetic recovery after the cold period may be delayed (Nardini and Salleo 2000). In severe cases leaves may desiccate. Since vulnerability to freeze/thaw-induced cavitation is highest in conduits with large diameter and volume (Davis et al. 1999; Zanne et al. 2014), evergreen species are expected to have smaller conduits relative to deciduous species (Cochard and Tyree 1990; Cordero and Nilsen 2002). Moreover, the size of pit pores determines the maximal size of particles that may pass into conduits and later cause ice nucleation (Lintunen et al. 2013). Small conduits with narrow pit pores, however, are hydraulically inefficient, potentially restricting gas exchange rates in evergreen species during warmer parts of the year (Tyree and Sperry 1989; Johnson et al. 2009).

According to the majority of reports, resistance of stem xylem to freeze-thaw induced cavitation is indeed correlated with leaf habit. Evergreen oaks had narrower vessels than deciduous oaks and were also less vulnerable to freeze induced cavitation both in the Mediterranean and in Florida (Cavender-Bares and Holbrook 2001; Cavender-Bares et al. 2005), similarly to a representative sample of arctic evergreen vs. deciduous shrubs and cushion plants (Gorsuch et al. 2001). Most evergreen chapparal species have relatively small-diameter vessels making them resistant to winter cavitation, however evergreen plants with larger vessels such as Rhus ovata and Malosma laurina suffered near complete loss of stem conductivity in subfreezing temperatures (Pratt et al. 2005). Two wide-vesseled Japanese evergreens underwent a severe reduction of stem conductivity and leaf dieback during winter, in contrast to two species with narrow-vessels (Taneda and Tateno 2005). Likewise, in an Australian high-altitude heath, evergreen species had variable conduit diameters and there was a close correlation between that trait and vulnerability to winter cavitation (Choat et al. 2011). Finally, based on a global study of plant radiation into freezing environments, among evergreen species only those with narrow $(<44 \mu \mathrm{m})$ conduits managed to colonize areas experiencing temperatures $<0^{\circ} \mathrm{C}$ (Zanne et al. 2014). Although not all studies cited here included deciduous species for comparison, the trend for narrower vessels in evergreens and a negative correlation between stem hydraulic efficiency and resistance to freeze-induced cavitation seems well established (Fu et al. 2012).

The stem hydraulic pathway is extended into the leaf vein system. Although similar biophysical principles govern the processes of water conduction and cavitation in leaves and in stems, leaves are a more complex system because they constitute a network of parallel and serial hydraulic resistors with much redundancy and large safety margins (Roth-Nebelsick et al. 2001). Whole leaf conductance integrates xylary and extra-xylary pathways of water movement and, depending on species, may or may not be constrained by hydraulic properties of the xylem conduits (Lo Gullo et al. 2003; Salleo et al. 2003). Declines of leaf hydraulic conductance may be caused by cavitation of xylem conduits but also by their collapse and by changes in the extra-xylary part of the pathway, such as drops in cell turgor or downregulation of mem- 
brane permeability (Sack and Holbrook 2006). Although loss of conductivity has been demonstrated under laboratory conditions in dehydrating leaves of Laurus nobilis (Salleo et al. 2001), Prunus laurocerasus (Nardini et al. 2001), Pieris japonica and Castanopis chrysophylla (Johnson et al. 2009), much less information is available on leaf hydraulic disruption due to freeze/thaw events. Leaves of Eucalyptus pauciflora subjected to $\mathrm{a}-6^{\circ} \mathrm{C}$ treatment followed by thawing experienced embolization of $1 / 3$ of vessels (Ball et al. 2006). There is also no clear evidence for superior resistance to hydraulic disruption in evergreen leaves. In contrast to stems, there is also generally no connection between leaf habit or LMA and leaf hydraulic conductance (Sack and Holbrook 2006). The few published studies specifically comparing leaf hydraulic properties of evergreen and deciduous species indicate that leaf habit is not a major determinant of leaf hydraulic conductance expressed on the leaf area basis (Lo Gullo et al. 2005; Sack and Frole 2006; Simonin et al. 2012).

This apparent absence of hydraulic specialization in evergreen leaves could be explained by the ultimate dependence of leaves on water supplied by stems. If stems, with their wider conduits, become embolized before the leaves, excessive hydraulic safety of leaf xylem would be of little value to the plant because leaves would become dehydrated anyway (Davis et al. 1999). In general, however, the leaf vein network is hydraulically safer than stems and, since cavitation first occurs in the midrib, its effect on whole leaf conductance may be mitigated by hydraulic bypasses formed by lateral veins (Nardini et al. 2001).

\section{Photosynthetic decline with leaf age}

Aging of evergreen leaves is typically accompanied by progressive self-shading by consecutive leaf cohorts (Ninemets et al. 2006; Wright et al. 2006; Falster et al. 2012). A gradual decrease of photosynthetic potential with age has been measured e.g. in Vaccinium vitis-idaea (by $75 \%$ in 6 -year-old leaves, Karlsson 1985), Laurus nobilis, Olea europaea and Quercus ilex (Niinemets et al. 2005). Such a decrease is in part caused by the thickening of cell walls that cause a greater internal resistance to $\mathrm{CO}_{2}$ diffusion (Niinemets et al. 2005; Niinemets 2007). In some species, such as Laurus nobilis, the decline in photosynthesis is concurrent with nitrogen withdrawal, but nitrogen concentration per area changed little during this process in Olea europaea or Quercus ilex (Niinemets et al. 2005).

Since the downregulation of photosynthetic capacity with age is, at least in some cases, independent of withdrawal of nitrogen to younger leaves, it is debat- able whether it represents an acclimative response to shade or merely a symptom of leaf aging (Hikosaka 2005; Niinemets 2007). In Quercus ilex both declining irradiance and leaf aging resulted in decreased photosynthetic capacity caused by lower nitrogen partitioning to rubisco and electron transport (Niinemets et al. 2006; Rodríguez-Calcerrada et al. 2012). Since both carboxylation and electron transport capacities were more closely related to current than to past irradiance, and an increase in leaf absorptance was reported, these changes may be considered to at least partly represent active shade acclimation (Niinemets et al. 2006; Niinemets 2007).

\section{Leaf acclimation to altered irradiance}

Leaves of evergreen understory species often develop and function in deep shade after the deciduous canopy closes. They become exposed to high irradiance after overstory leaves have fallen in the autumn. Acclimative adjustments of leaf structure and photosynthetic potential allow the plants to deal with spatial and seasonal variability of ambient irradiance.

In response to altered light intensity, evergreen species show plastic modifications of leaf structure that are similar in direction to those of deciduous species [e.g. see Letts et al. (2012) for data on Buxus sempervirens, Valladares et al. (2005) for Ilex aquifolium, Gratani et al. (2006) and Tattini et al. (2006) for Quercus ilex, Phillyrea latifolia, Pistacia lentiscus and Myrtus communis]. Leaves formed in low light are thin, have low LMA and tissue density, and a low photosynthetic capacity per area, consistent with the need to adjust carbon investment costs to anticipated photosynthetic benefits in a low light environment (Poorter et al. 2009; Lusk et al. 2010). Extended life span, however, requires high LMA and tough leaf structure also under shaded conditions, therefore it may be hypothesized that the capacity for plastic modification of leaf structure should be lower in evergreen than in deciduous leaves (Lusk et al. 2008). Surprisingly few comparisons of quantitative reaction norms of these contrasting leaf types have been conducted. Data from Valladares et al. (2000) for 16 species of neotropical Psychotria shrubs indicate no connection between leaf longevity and the plasticity index measuring the response of LMA to irradiance. Likewise, plasticity of LMA in the evergreen Quercus suber was similar to that in the deciduous $Q$. canariensis (Daas-Ghrib et al. 2011). On the other hand, response of LMA to a canopy light gradient in Ilex aquifolium was smaller than for most deciduous species studied by Aranda et al. (2004). In a greenhouse experiment, average plasticity index for LMA was 
$35 \%$ in 36 deciduous species and only $18 \%$ in 35 evergreen species from subtropical China (Böhnke and Bruelheide 2013). Given the large number of species included in the latter study, the hypothesis that evergreen leaf habit is associated with reduced plasticity of leaf structure in comparison with deciduous species, seems valid.

The conflict between longevity and plasticity may be attenuated by several factors. A detailed analysis of leaf plasticity in tropical evergreen species conducted by Lusk et al. (2010) showed that the reduction of LMA in shade did not cause a proportional decrease in leaf mechanical properties. In fact, at similar LMA, shade leaves were stronger than sun leaves, reflecting their slightly higher leaf density and cell wall fraction while specific cell wall strength was unchanged. Further, the decrease of LMA (a trait contributing to herbivore resistance) in shade, could be compensated for by the lower attractiveness of shade leaves to herbivores due to their lower nutritional contents per unit force needed to ingest the leaf tissue (Lusk et al. 2010).

Interestingly, even constitutive shade tolerance in woody evergreens does not require the expression of the typical low LMA syndrome. Numerous evergreen species, especially in tropical forests, are primarily adapted to shade while retaining structural characteristics normally associated with longevity (Lusk et al. 2008). This strategy is viable because evergreen plants in low light achieve a favorable lifetime carbon balance not by maximally reducing leaf construction costs, but rather by extending their life spans, decreasing respiratory costs and plant growth rate (Walters and Reich 1999; Lusk 2008).

Regardless of the leaf habit, there are few exceptions to the rule that structural adjustment to ambient irradiance takes place during the expansion phase of the leaf lamina. Surprisingly, one of the most remarkable of those exceptions has been described in the evergreen Hedera helix, in which mature, previous-year, shade-acclimated leaves responded to increased light by the division and expansion of cells in the upper mesophyll layer (Bauer and Thöni 1988). In some evergreen species, lamina development is slow and the maturation of photosynthetic apparatus even slower ("delayed greening") which allows a longer time window when structural acclimation to increased light is possible (Ishii and Ohsugi 2011). Reports of late structural adjustments are, however, rare, in contrast to physiological acclimation. Even mature, previous-season leaves may respond to increased irradiance by increasing their $\mathrm{N}$ content and photosynthetic capacity without undergoing structural modifications (Ishii and Ohsugi 2011).

\section{Leaf development rate}

Leaf development consists of lamina expansion, development of internal and external anatomical structures and acquisition of photosynthetic competence. Leaves tend to reach peak $A_{\max (a r e a)}$ at, or soon before, the completion of the lamina expansion (Pantin et al. 2012). The rates of lamina expansion and acquisition of functional maturity tend to be slow in species with high LMA (Miyazawa et al. 1998; Gratani and Bonito 2009). An extreme case of this phenomenon has been termed "delayed greening" and involves a slow build-up of leaf chlorophyll content and photosynthetic capacity after full lamina expansion. It has been widely observed in many, especially shade tolerant, tropical trees (Kursar and Coley 1992a). This phenomenon has rarely been reported from northern temperate areas but it is common e.g. in warm temperate forests in Japan where it is a feature of many evergreen trees. Between 15 and 44 days were required to achieve full photosynthesis after completion leaf area expansion in Neolitsea sericea, Quercus glabra, Q. myrsinifolia, Machilus thunbergii, Castanopsis sieboldii and Cinnamomum japonicum (Miyazawa et al. 1998). The delay was correlated with the final LMA, suggesting that longer time is needed to form a fully functional internal structure in the tough, evergreen leaves (Miyazawa et al. 1998). Delayed greening has also been interpreted as an adaptive mechanism minimizing losses to herbivory by producing sufficiently resistant leaf tissues before investing resources in photosynthesis (Kursar and Coley 1992b). The development of leaf area and photosynthetic capacity seem, however, to be well synchronized in other evergreens, e.g. the Mediterranean Arbutus unedo (Gratani and Ghia 2002) or Quercus ilex (Gratani and Bonito 2009).

\section{Evergreen leaves as storage organs}

Seasonal growth rhythms in perennial plants are accompanied by rhythms of resource uptake, accumulation and mobilization (Chapin et al. 1990). Early season initiation of new shoot growth is supported to various extents by stored carbohydrates. Whereas in deciduous plants the only source of carbohydrates at that time is the storage pool, evergreen species rely both on storage and on current assimilation by preexisting leaves. Moreover, in addition to carbohydrates accumulated in axial organs, as is typical for all woody plants, evergreen species may store part of their carbohydrate pool in overwintering leaves. According to Miyaké (1902), this idea was historically suggested by Sachs in his 1862 paper published in Flora. A semi-quantitative study by Miyaké (1902), however, showed, that during the coldest months 


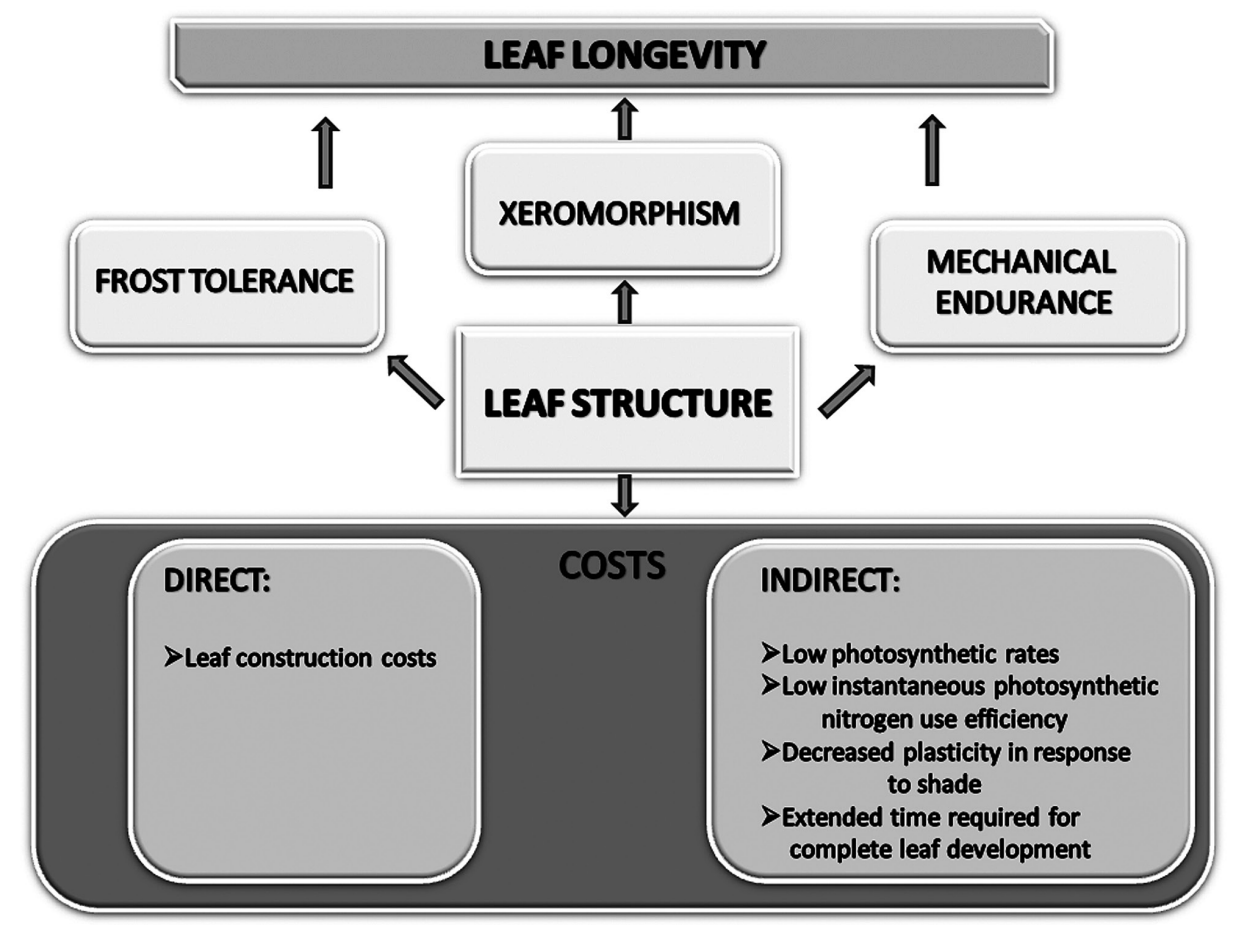

Fig. 4. A synthetic view of structural modifications found in evergreen leaves (enhanced mechanical endurance, frost tolerance and water deficit tolerance) required for leaf longevity and incurring direct and indirect costs to the plant

starch concentration in overwintering leaves is usually lower than during the rest of the year, and in many species starch is nearly absent. It does, however accumulate during early spring, before shoot growth begins. Soluble carbohydrates may also be present acting as osmotica in winter and later used as energy sources (Reyes-Díaz et al. 2005). The role of leaves as storage site has since been suggested by numerous phenological and manipulative studies. For example, the period of springtime shoot extension in Quercus ilex coincided with a decrease in soluble sugar, hemicelulose, and lipid pools in at least some age classes of preexisting leaves (Cherbuy et al. 2001). Total nonstructural carbohydrate level in a Mediterranean plant Salvia lavandulifolia leaves increased between November and February and declined thereafter when new shoots were expanding (Palacio et al. 2007). Winter carbohydrate levels were high in recent-leaf cohorts of Aucuba japonica, Camellia rusticana, Ilex crenata and Daphniphyllum macropodium and declined later in the year presumably because of export and consumption by growing plant parts (Ino et al. 2003). Removal of mature leaves from Kalmia polifolia, Ledum groenlandicum (Reader 1978) and Quercus ilex (Cherbuy et al. 2001) at the end of winter decreased the storage pools and resulted in a decreased growth of new shoots and foliage. Such results are suggestive of significant resource storage in leaves. However, in the case of defoliation treatments, the plant also loses part of its assimilatory surface that would otherwise contribute to regrowth.
In addition to carbohydrates, defoliation treatments remove certain amounts of nutrients that might possibly also function as a storage pool. The storage of nitrogen in protein form in leaves is suggested by the elevated fraction of inactive rubisco (Takashima et al. 2004). Also, the patterns of seasonal variability in leaf nitrogen concentration often indicate an accumulation of this nutrient during the growth season followed by springtime translocation into new growing shoots, as documented e.g. for Satureia montana (Palacio et al. 2007), Daphniphyllum humile (Katahata et al. 2007) and Quercus ilex (Cherbuy et al. 2001). The withdrawal of nutrients from mature leaves may also be interpreted as nutrient recycling accompanying senescence, similar as in deciduous species but less rapid. This is especially likely in species where timing of leaf senescence and nutrient remobilization do not match the timing of new growth (Milla et al. 2005). In Rhododendron ferrugineum, tracing the $\mathrm{N}^{15}$ label revealed that nearly $70 \%$ of nitrogen resorption from leaves took place within the first 12 months of their life (leaf life span was up to 25 months in this species) and $26 \%$ of the label was recovered from new shoots (Pornon and Lamaze 2007). Essentially, in this species the second and final season of life was an extended senescence accompanied by a decline in photosynthetic rate and chlorophyll concentration. The blurry distinction between mobilization of nitrogen from the storage pool and its resorption from senescing leaves, is further complicated by the fact that in young, nonse- 
nescent leaf cohorts, resorption and replenishment of nutrient pools may occur concurrently (Pasche et al. 2002).

A convincing case of nitrogen storage has been described in Quercus myrsinifolia, in which nitrogen accumulated during the first season of leaves' life was partially resorbed in the spring, followed by another period of moderate accumulation and resorption before leaf abscission at the end of the second season (Yasumura and Ishida 2010). Leaves of this tree thus performed a full accumulation-mobilization-accumulation cycle. A potential physiological mechanism for seasonal storage of nitrogen has been documented in high-light grown Aucuba japonica in which $\mathrm{N}_{\mathrm{ar}}$ ea increased before the winter followed by a spring decrease (Muller et al. 2009). Much mesophyll cell wall area was initially free of chloroplasts. That vacant space was filled by expanding chloroplasts as winter approached, accompanied by the accumulation of rubisco with reduced activity (Muller et al. 2009). In this case authors favored the interpretation of rubisco accumulation as a photosynthetic acclimatory mechanism, compensating for limitation of photosynthesis by low winter temperatures. Nitrogen storage in leaves would clearly be a side effect of such acclimation since nitrogen was withdrawn from leaves in the following spring (Muller et al. 2011). In the understory shrub Kalmia latifolia, gradual accumulation of nitrogen during summer when plants are shaded may be viewed as building up of the storage pool, perhaps facilitated by lower demand from other sinks or by nutrient recycling from other senescing organs (Xu et al. 2007).

The role of resources accumulated in preexisting leaves for initiation of growth will vary from crucial to null depending on the diversity of growth phenologies, leaf longevities and species specific strategies and allocation patterns (Eckstein et al. 1998; Milla et al. 2005; Palacio et al. 2006). It is certainly different for different resource types (with little information available e.g. on phosphorus storage) and on habitat characteristics. Especially where leaf damage during the winter is likely, other storage sites within the plant should become more important (Palacio et al. 2007).

\section{Summary}

In seasonal climates, adaptation of leaves to survive more than one growing season requires the presence of special structural, developmental and physiological adaptations, most of which involve costs and trade-offs with other plant functions (Fig. 4). Direct costs take the form of additional resource investment into making leaf mechanical tissues. Indirect costs may include reduced photosynthetic effi- ciency and PNUE, slower leaf development, smaller leaf plasticity and greater self shading as well as lower hydraulic efficiency of the xylem. With the rapidly increasing understanding of adaptive physiology of particular traits and the associated costs, progress is being made towards answering key questions in evolutionary ecology of plants differing in leaf habit.

\section{Acknowledgement}

This work was supported by Polish Ministry of Science and Higher Education Grant NN 304066537 (2009-2012) to T. Wyka.

\section{References}

Ackerly D.D. 2004. Functional strategies of chaparral shrubs in relation to seasonal water deficit and disturbance. Ecological Monographs 74: 25-44. http://dx.doi.org/10.1890/03-4022

Adams W.W. III, Demmig-Adams B., Rosenstiel T.N., Brightwell A.K., Ebbert V. 2002. Photosynthesis and photoprotection in overwintering plants. Plant Biology 4: 545-557. http://dx.doi. org/10.1055/s-2002-35434

Adams W.W. III, Zarter C.R., Ebbert V., Demmig-Adams B. 2004. Photoprotective strategies of overwintering evergreens. BioScience 54: 41-49. http://dx.doi.org/10.1641/0006-3568(2004)054[0041:PSOOE]2.0.CO;2

Aerts R. 1995. The advantages of being evergreen. Trends in Ecology and Evolution 10: 402-407. http://dx.doi.org/10.1016/S0169$5347(00) 89156-9$

Alvarez-Clare S., Kitajima K. 2007. Physical defence traits enhance seedling survival of neotropical tree species. Functional Ecology 21: 1044-1054. http://dx.doi.org/10.1111/j.13652435.2007.01320.x

Aranda I., Pardo F., Gil L., Pardos J.A. 2004. Anatomical basis of the change in leaf mass per area and nitrogen investment with relative irradiance within the canopy of eight temperate tree species. Acta Oecologica 25: 187-195. http://dx.doi. org/10.1016/j.actao.2004.01.003

Arena C., Vitale L., Virzo De Santo A. 2006. Annual dynamics of photosynthetic activity and photoprotective strategies in seedlings of Phillyrea angustifolia L. Poster at $16^{\text {th }}$ meeting of the Italian Society of Ecology (http://www.ecologia.it/congressi/XVI/articles/arena-170.pdf).

Ball M.C., Canny M.J., Huang C.X., Heady R.D. 2004. Structural changes in acclimated and unacclimated leaves during freezing and thawing. 
Functional Plant Biology 31: 29-40. http://dx. doi.org/10.1071/FP03164

Ball M.C., Canny M.J., Huang C.X., Egerton J.J.G., Wolfe J. 2006. Freeze/thaw-induced embolism depends on nadir temperature: the heterogenous hydration hypothesis. Plant, Cell and Environment 29: 729-745. http://dx.doi.org/10.1111/ j.1365-3040.2005.01426.x

Balsamo R.A., Bauer A.M., Davis S.D., Rice B.M. 2003. Leaf biomechanics, morphology, and anatomy of the deciduous mesophyte Prunus serrulata (Rosaceae) and the evergreen sclerophyllous shrub Heteromeles arbutifolia (Rosaceae). American Journal of Botany 90: 72-77. http://dx.doi. org/10.3732/ajb.90.1.72

Bao Y.J., Nilsen E.T. 1988. The ecological significance of leaf movements in Rhododendron maximum. Ecology 69: 1578-1587. http://dx.doi. org/10.2307/1941655

Bauer H., Kofler R. 1987. Photosynthesis in frost-hardened and frost-stresses leaves of Hedera helix L. Plant, Cell and Environment 10: 339-346. http://dx.doi.org/10.1111/j.1365-3040.1987. tb01615.x

Bauer H., Thöni W. 1988. Photosynthetic light acclimation in fully developed leaves of the juvenile and adult life phases of Hedera helix. Physiologia Plantarum 73: 31-37. http://dx.doi. org/10.1111/j.1399-3054.1988.tb09189.x

Blennow K., Lang A.R.G., Dunne P., Ball M.C. 1998. Cold-induced photoinhibition and growth of seedling snow gum (Eucalyptus pauciflora) under differing temperature and radiation regimes in fragmented forests. Plant, Cell and Environment 21: 407-416. http://dx.doi.org/10.1046/j.13653040.1998.00291.x

Böhnke M., Bruelheide H. 2013. How do evergreen and deciduous species respond to shade? Tolerance and plasticity of subtropical tree and shrub species of South-East China. Environmental and Experimental Botany 87: 179-190. http://dx.doi. org/10.1016/j.envexpbot.2012.09.010

Burghardt M., Riederer M. 2003. Ecophysiological relevance of cuticular transpiration of deciduous and evergreen plants in relation to stomatal closure and leaf water potential. Journal of Experimental Botany 54: 1941-1949. http://dx.doi. org/10.1093/jxb/erg195

Cavender-Bares J., Cortes P., Rambal S., Joffre R., Miles B., Rocheteau A. 2005. Summer and winter sensitivity of leaves and xylem to minimum freezing temperatures: a comparison of co-occurring Mediterranean oaks that differ in leaf lifespan. New Phytologist 168: 597-612. http://dx.doi. org/10.1111/j.1469-8137.2005.01555.x

Cavender-Bares J., Holbrook N.M. 2001. Hydraulic properties and freezing-induced cavitation in sympatric evergreen and deciduous oaks with contrasting habitats. Plant, Cell and Environment 24: 1243-1256. http://dx.doi.org/10.1046/ j.1365-3040.2001.00797.x

Chabot B.F., Hicks D.J. 1982. The ecology of leaf life spans. Annual Review of Ecology and Systematics 13: 229-259. http://dx.doi.org/10.1146/annurev. es.13.110182.001305

Chapin F.S. III, Schulze E.-D., Mooney H.A. 1990. The ecology and economics of storage in plants. Annual Review of Ecology and Systematics 21: 423-447. http://dx.doi.org/10.1146/annurev. es.21.110190.002231

Cherbuy B., Joffre R., Gillon D., Rambal S. 2001. Internal remobilization of carbohydrates, lipids, nitrogen and phosphorus in the Mediterranean evergreen oak Quercus ilex. Tree Physiology 21: 9-17. http://dx.doi.org/10.1093/treephys/21.1.9

Choat B., Medek D.E., Stuart S.A., Pasquet-Kok J., Egerton J.J.G., Salari H., Sack L., Ball M.C. 2011. Xylem traits mediate a trade-off between resistance to freeze-thaw-induced embolism and photosynthetic capacity in overwintering evergreens. New Phytologist 191: 996-1005. http://dx.doi. org/10.1111/j.1469-8137.2011.03772.x

Cochard H., Tyree M.T. 1990. Xylem dysfunction in Quercus: vessel size, tyloses, cavitation and seasonal changes in embolism. Tree Physiology 6: 393407. http://dx.doi.org/10.1093/treephys/6.4.393

Corcuera L., Morales F., Abadia A., Gil-Pelegrin E. 2005. The effect of low temperature on the photosynthetic apparatus of Quercus ilex subsp. ballota at its lower and upper altitudinal limits in the Iberian peninsula and during a single freezing-thawing cycle. Trees 19: 99-108. http://dx. doi.org/10.1007/s00468-004-0368-1

Cordero R.A., Nilsen E.T. 2002 Effects of summer drought and winter freezing on stem hydraulic conductivity of Rhododendron species from contrasting climates. Tree Physiology 22: 919-928. http://dx.doi.org/10.1093/treephys/22.13.919

Daas-Ghrib C., Montpied P., Ksontini M., Dreyer E. 2011. Functional relationships between leaf structure and photosynthetic traits as modulated by irradiance and nutrient availability in a sclerophyllous and a non-sclerophyllous mediterranean oak species. European Journal of Forest Research 130: 503-512. http://dx.doi.org/10.1007/ s10342-010-0438-4

Davis S.D., Sperry J.S., Hacke U.G. 1999. The relationship between xylem conduit diameter and cavitation caused by freezing. American Journal of Botany 86: 1367-1372. http://dx.doi. org/10.2307/2656919

Eckstein R.L., Karlsson P.S., Weih M. 1998. The significance of resorption of leaf resources for shoot growth in evergreen and deciduous woody plants 
from a subarctic environment. Oikos 81: 567-575. http://dx.doi.org/10.2307/3546777

Ellsworth D.S., Reich P.B., Naumburg E.S., Koch G.W., Kubiske M.E., Smith S.D. 2004. Photosynthesis, carboxylation and leaf nitrogen responses of 16 species to elevated $\mathrm{CO}_{2}$ across four free-air $\mathrm{CO}_{2}$ enrichment experiments in forest, grassland and desert. Global Change Biology 10: 2121-2138. http://dx.doi.org/10.1111/j.13652486.2004.00867.x

Evans J.R., Jakobsen I., Ögren E. 1993. Photosynthetic light-response curves. 2. Gradients of light-absorption and photosynthetic capacity. Planta 189: 191-200. http://dx.doi.org/10.1007/ BF00195076

Evans J.R., Kaldenhoff R., Genty B., Terashima I. 2009. Resistances along the $\mathrm{CO}_{2}$ diffusion pathway inside leaves. Journal of Experimental Botany 60: 2235-2248. http://dx.doi.org/10.1093/jxb/ erp117

Ewers F.W., Schmid R. 1981. Longevity of needle fascicles of Pinus longaeva (Bristlecone pine) and other North American pines. Oecologia 51: 107-115. http://dx.doi.org/10.1007/BF00344660

Fahn A., Cutler D.F. 1992. Xerophytes. Encyclopedia of plant anatomy. Vol. XIII.3. Gebrüder Borntraeger, Berlin, $176 \mathrm{p}$.

Falster D.S., Reich P.B., Ellsworth D.S., Wright I.J., Westoby M., Oleksyn J., Lee T.D. 2012. Lifetime return on investment increases with leaf lifespan among 10 Australian woodland species. New Phytologist 193: 409-419. http://dx.doi. org/10.1111/j.1469-8137.2011.03940.x

Field C., Mooney H.A. 1986. The photosynthesis-nitrogen relationship in wild plants. In: On the economy of form and function. Givnish T.J. (ed.). Cambridge University Press, Cambridge, pp. 2555.

Fu P.-L., Jiang Y.-J., Wang A.-Y., Brodribb T.J., Zhang J.-L., Zhu S.-D., Cao K.-F. 2012. Stem hydraulic traits and leaf water-stress tolerance are co-ordinated with the leaf phenology of angiosperm trees in an Asian tropical dry karts forest. Annals of Botany 110: 189-199. http://dx.doi.org/10.1093/ $\mathrm{aob} / \mathrm{mcs} 092$

García-Plazaola J.I., Artetxe U., Duñabeitia M.K., Becerril J.M. 1999. Role of photoprotective systems of holm-oak (Quercus ilex) in the adaptation to winter conditions. Journal of Plant Physiology 155: 625-630. http://dx.doi.org/10.1016/S01761617(99) 80064-9

García-Plazaola J.I., Olano J.M., Hernández A., Becerril J.M. 2003. Photoprotection in evergreen Mediterranean plants during sudden periods of intense cold weather. Trees 17: 285-291.

Gilmore A.M., Ball M.C. 2000. Protection and storage of chlorophyll in overwintering evergreens.
Proceedings of National Academy of Sciences of the United States of America 97: 11098-11101. http://dx.doi.org/10.1073/pnas.150237697

Givnish T.J. 2002. Adaptive significance of evergreen vs. deciduous leaves: solving the triple paradox. Silva Fennica 36: 703-743.

Gorsuch D.M., Oberbauer S.F., Fisher J.B. 2001. Comparative vessel anatomy of arctic deciduous and evergreen dicots. American Journal of Botany 88: 1643-1649. http://dx.doi.org/10.2307/3558409

Gostin I.N., Ivanescu L. 2008. Leaf structure and development in Buxus sempervirens L. Natura Montenegrina $7: 27-32$.

Grace S.C., Logan B.A., Adams W.W. III. 1998. Seasonal differences in foliar content of chlorogenic acid, a phenylpropanoid antioxidant, in Mahonia repens. Plant, Cell and Environment 21: 513-521. http:// dx.doi.org/10.1046/j.1365-3040.1998.00282.x

Gratani L., Bonito A. 2009. Leaf traits variation during leaf expansion in Quercus ilex L. Photosynthetica 47: 323-330. http://dx.doi.org/10.1007/ s11099-009-0052-1

Gratani L., Covone F., Larcher W. 2006. Leaf plasticity in response to light of three evergreen species of the Mediterranean maquis. Trees 20: 549-558. http://dx.doi.org/10.1007/s00468-006-0070-6

Gratani L., Crescente M.F. 1997. Phenology and leaf adaptive strategies of Mediterranean maquis plants. Ecologia Mediterranea 23: 11-19.

Gratani L., Ghia E. 2002. Changes in morphological and physiological traits during leaf expansion of Arbutus unedo. Environmental and Experimental Botany 48: 51-60. http://dx.doi.org/10.1016/ S0098-8472(02)00010-2

Green D.S., Kruger E.L. 2001. Light-mediated constraints on leaf function correlate with leaf structure among deciduous and evergreen tree species. Tree Physiology 21: 1341-1346. http://dx.doi. org/10.1093/treephys/21.18.1341

Groom Q.J., Baker N.R., Long S.P. 1991. Photoinhibition of holly (Ilex aquifolium) in the field during the winter. Physiologia Plantarum 83: 585-590. http://dx.doi.org/10.1111/j.1399-3054.1991. tb02472.x

Hacker J., Neuner G. 2007. Ice propagation in plants visualized at the tissue level by infrared differential thermal analysis (IDTA). Tree Physiology 27: 1661-1670. http://dx.doi.org/10.1093/treephys/27.12.1661

Hacker J., Neuner G. 2008. Ice propagation in dehardened alpine plant species studied by infrared differential thermal analysis (IDTA). Arctic, Antarctic and Alpine Research 40: 660-670. http:// dx.doi.org/10.1657/1523-0430(07-077) [HACKER]2.0.CO;2

Hanba Y.T., Miyazawa S.-I., Terashima I. 1999. The influence of leaf thickness on the $\mathrm{CO}_{2}$ transfer 
conductance and leaf stable carbon isotope ratio for some evergreen tree species in Japanese warm-temperate forests. Functional Ecology 13: 632-639. http://dx.doi.org/10.1046/j.13652435.1999.00364.x

Harris G.C., Antoine V., Chan M., Nevidomskyte D., Königer M. 2006. Seasonal changes in photosynthesis, protein composition and mineral content in Rhododendron leaves. Plant Science 170: 314-325. http://dx.doi.org/10.1016/j.plantsci.2005.08.024

Harrison M.T., Edwards E.J., Farquhar G.D., Nicotra A.B., Evans J.R. 2009. Nitrogen in cell walls of sclerophyllous leaves accounts for little of the variation in photosynthetic nitrogen-use efficiency. Plant, Cell and Environment 32: 259-270. http:// dx.doi.org/10.1111/j.1365-3040.2008.01918.x

Hassiotou F., Ludwig M., Renton M., Veneklaas E.J., Evans J.R. 2009. Influence of leaf dry mass per area, $\mathrm{CO}_{2}$, and irradiance on mesophyll conductance in sclerophylls. Journal of Experimental Botany 60: 2303-2314. http://dx.doi.org/10.1093/ $\mathrm{jxb} / \mathrm{erp} 021$

Hassiotou F., Ludwig M., Renton M., Veneklaas E.J., Evans J.R., 2010. Photosynthesis at an extreme end of the leaf trait spectrum: how does it relate to high leaf dry mass per area and associated structural parameters? Journal of Experimental Botany 61: 3015-3028. http://dx.doi.org/10.1093/jxb/ erq128

Hikosaka K. 2005. Leaf canopy as a dynamic system: ecophysiology and optimality in leaf turnover. Annals of Botany 95: 521-533. http://dx.doi. org/10.1093/aob/mci050

Hikosaka K., Hirose T. 2000. Photosynthetic nitrogen-use efficiency in evergreen broad-leaved woody species coexisting in a warm-temperate forest. Tree Physiology 20: 1249-1254. http://dx. doi.org/10.1093/treephys/20.18.1249

Hikosaka K., Shigeno A. 2009. The role of Rubisco and cell walls in the interspecific variation in photosynthetic capacity. Oecologia 160: 443-451. http://dx.doi.org/10.1007/s00442-009-1315-z

Hormaetxe K., Becerril J.M., Hernández A., Esteban R., García-Plazaola J.I. 2007. Plasticity of photoprotective mechanisms of Buxus sempervirens $\mathrm{L}$. leaves in response to extreme temperatures. Plant Biology 9: 59-68. http://dx.doi. org/10.1055/s-2006-924456

Hormaetxe K., Hernández A., Becerril J.M., García-Plazaola J.I. 2004. Role of red carotenoids in photoprotection during winter acclimation in Buxus sempervirens leaves. Plant Biology 6: 325332. http://dx.doi.org/10.1055/s-2004-817883

Hughes N.M. 2011. Winter leaf reddening in 'evergreen' species. New Phytologist 190: 573-581. http://dx.doi.org/10.1111/j.14698137.2011.03662.x
Hughes N.M., Burkey K.O., Cavender-Bares J., Smith W. 2012. Xanthophyll cycle pigment and antioxidant profiles of winter-red (anthocyanic) and winter-green (acyanic) angiosperm evergreen species. Journal of Experimental Botany 63: 1895-1905. http://dx.doi.org/10.1093/jxb/err362

Ino Y., Maekawa T., Shibayama T., Sakamaki Y. 2003. Two types of matter economy for the wintering of evergreen shrubs in regions of heavy snowfall. Journal of Plant Research 116: 327-330. http:// dx.doi.org/10.1007/s10265-003-0101-y

Ishii H., Ohsugi Y. 2011. Light acclimation potential and carry-over effects vary among three evergreen tree species with contrasting patterns of leaf emergence and maturation. Tree Physiology 31: 819-830. http://dx.doi.org/10.1093/treephys/ tpr079

Ishikawa M. 1984. Deep supercooling in most tissues of wintering Sasa senanensis and its mechanism in leaf blade tissues. Plant Physiology 75: 196-202. http://dx.doi.org/10.1104/pp.75.1.196

Johnson D.M., Meinzer F.C., Woodruff D.R., McCulloh K.A. 2009. Leaf xylem embolism, detected acoustically and by cryo-SEM, corresponds to decreases in leaf hydraulic conductance in four evergreen species. Plant, Cell and Environment 32: 828-836. http://dx.doi.org/10.1111/j.13653040.2009.01961.x

Jordan G.J., Brodribb T.J., Blackman C.J., Weston P.H. 2013. Climate drives vein anatomy in Proteaceae. American Journal of Botany 100: 1483-1493. http://dx.doi.org/10.3732/ajb.1200471

Jordan G.J., Dillon R.A., Weston P.H. 2005. Solar radiation as a factor in the evolution of scleromorphic leaf anatomy in Proteaceae. American Journal of Botany 92: 789-796. http://dx.doi.org/10.3732/ ajb.92.5.789

Juárez-López FJ., Escudero A., Mediavilla S. 2008. Ontogenetic changes in stomatal and biochemical limitations to photosynthesis of two co-occurring Mediterranean oaks differing in leaf life span. Tree Physiology 28: 367-374. http://dx.doi. org/10.1093/treephys/28.3.367

Karabourniotis G. 1998. Light-guiding function of foliar sclereids in the evergreen sclerophyll Phillyrea latifolia: a quantitative approach. Journal of Experimental Botany 49: 739-746. http://dx.doi. org/10.1093/jxb/49.321.739

Karlsson P.S. 1985. Photosynthetic characteristics and leaf carbon economy of a deciduous and an evergreen dwarf shrub: Vaccinium uliginosum L. and V. vitis-idaea L. Ecography 8: 9-17. http://dx.doi. org/10.1111/j.1600-0587.1985.tb01147.x

Karlsson P.S. 1992. Leaf longevity in evergreen shrubs: variation within and among European species. Oecologia 91: 346-349. http://dx.doi. org/10.1007/BF00317622 
Katahata S.-I., Naramoto M., Kakubari Y., Mukai Y. 2007. Seasonal changes in photosynthesis and nitrogen allocation in leaves of different ages in evergreen understory shrub Daphniphyllum humile. Trees 21: 619-629. http://dx.doi.org/10.1007/ s00468-007-0155-x

Khanal B.P., Grimm E., Finger S., Blume A., Knoche M. 2013. Intracuticular wax fixes and restricts strain in leaf and fruit cuticles. New Phytologist 200: 134-143. http://dx.doi.org/10.1111/ nph. 12355

Kikuzawa K., Lechowicz M.J. 2011. Ecology of leaf longevity. Springer, Berlin, 147 p. http://dx.doi. org/10.1007/978-4-431-53918-6

Kitajima K., Llorens A.-M., Stefanescu C., Timchenko M.V., Lucas P.W., Wright S.J. 2012. How cellulose-based leaf toughness and lamina density contribute to long leaf lifespans of shade-tolerant species. New Phytologist 195: 640-652. http://dx.doi.org/10.1111/j.1469-8137.2012.04203.x

Körner C. 2003. Alpine plant life: Functional plant ecology of high mountain ecosystems. Springer, Berlin, 349 p. http://dx.doi.org/10.1007/978-3642-18970-8

Kursar T.A., Coley P.D. 1992a. Delayed development of the photosynthetic apparatus in tropical rain forest species. Functional Ecology 6: 411-422. http://dx.doi.org/10.2307/2389279

Kursar T.A., Coley P.D. 1992b. Delayed greening in tropical leaves: an antiherbivore defense? Biotropica 24: 256-262. http://dx.doi. org/10.2307/2388520

Kyparissis A., Drilias P., Manetas, Y. 2000. Seasonal fluctuations in photoprotective (xanthophyll cycle) and photoselective (chlorophylls) capacity in eight Mediterranean plant species belonging to two different growth forms. Australian Journal of Plant Physiology 27: 265-272.

Larcher W., Siegwolf R. 1985. Development of acute frost drought in Rhododendron ferrugineum at the alpine timberline. Oecologia 67: 298-300. http:// dx.doi.org/10.1007/BF00384304

Letts M.G., Rodríguez-Calcerrada J., Rolo V., Rambal S. 2012. Long-term physiological and morphological acclimation by the evergreen shrub Buxus sempervirens L. to understory and canopy gap light intensities. Trees 26: 479-491. http://dx.doi. org/10.1007/s00468-011-0609-z

Lintunen A., Hölttä T., Kulmala M. 2013. Anatomical regulation of ice nucleation and cavitation helps trees to survive freezing and drought stress. Scientific Reports 3, 2031; DOI: 10.1038/srep02031. http://dx.doi.org/10.1038/srep02031

Lo Gullo M.A., Nardini A., Trifilò P., Salleo S. 2003. Changes in leaf hydraulics and stomatal conductance following drought stress and irrigation in Ceratonia siliqua (Carob tree). Physiologia Plan- tarum 117: 186-194. http://dx.doi.org/10.1034/ j.1399-3054.2003.00038.x

Lo Gullo M.A., Nardini A., Trifilò P., Salleo S. 2005. Diurnal and seasonal variations in leaf hydraulic conductance in evergreen and deciduous trees. Tree Physiology 25: 505-512. http://dx.doi. org/10.1093/treephys/25.4.505

Lo Gullo M.A., Salleo S. 1988. Different strategies of drought resistance in three Mediterranean sclerophyllous trees growing in the same environmental conditions. New Phytologist 108: 267-276. http://dx.doi.org/10.1111/j.1469-8137.1988. tb04162.x

Logan B.A., Grace S.C., Adams W.W. III, Demmig-Adams B. 1998. Seasonal differences in xanthophyll cycle characteristics and antioxidants in Mahonia repens growing in different light environments. Oecologia 116: 9-17.

Loreto F., Harley P.C., Di Marco G., Sharkey T.D. 1992. Estimation of mesophyll conductance to $\mathrm{CO}_{2}$ flux by three different methods. Plant Physiology 98: 1437-1443. http://dx.doi.org/10.1104/ pp.98.4.1437

Lundell R., Saarinen T., Åström H., Hänninen H. 2008. The boreal dwarf shrub Vaccinium vitis-idaea retains its capacity for photosynthesis through the winter. Botany 86: 491-500. http://dx.doi. org/10.1139/B08-022

Lusk C.H., Onoda Y., Kooyman R., Guttiérez-Girón A. 2010. Reconciling species-level vs plastic responses of evergreen leaf structure to light gradients: shade leaves punch above their weight. New Phytologist 186: 429-438. http://dx.doi. org/10.1111/j.1469-8137.2010.03202.x

Lusk C.H., Reich P.B., Montgomery R.A., Ackerly D.D., Cavender-Bares J. 2008. Why are evergreen leaves so contrary about shade? Trends in Ecology and Evolution 23: 299-303. http://dx.doi. org/10.1016/j.tree.2008.02.006

Marchi S., Tognetti R., Minocci A., Borghi M., Sebastiani L. 2008. Variation in mesophyll anatomy and photosynthetic capacity during leaf development in a deciduous mesophyte fruit tree (Prunus persica) and an evergreen sclerophyllous Mediterranean shrub (Olea europea). Trees 22: 559-571. http://dx.doi.org/10.1007/s00468-008-0216-9

Marty C., Lamaze T., Pornon A. 2009. Endogenous sink-source interactions and soil nitrogen regulate leaf life-span in an evergreen shrub. New Phytologist 183: 1114-1123. http://dx.doi.org/10.1111/ j.1469-8137.2009.02893.x

Mediavilla S., Escudero A., Heilmeier H. 2001. Internal leaf anatomy and photosynthetic resource-use efficiency: interspecific and intraspecific comparisons. Tree Physiology 21: 251-259. http://dx.doi. org/10.1093/treephys/21.4.251 
Mediavilla S., Garcia-Ciudad A., Garcia-Criado B., Escudero A. 2008. Testing the correlations between leaf life span and leaf structural reinforcement in 13 species of European Mediterranean woody plants. Functional Ecology 22: 787-793. http:// dx.doi.org/10.1111/j.1365-2435.2008.01453.x

Mediavilla S., Santiago H., Escudero A. 2002. Stomatal and mesophyll limitations to photosynthesis in one evergreen and one deciduous Mediterranean oak species. Photosynthetica 40: 553-559. http://dx.doi.org/10.1023/A:1024399919107

Meletiou-Christou M.-S., Rhizopoulou S. 2012. Constraints of photosynthetic performance and water status of four evergreen species co-occurring under field conditions. Botanical Studies 53: 325-334.

Milla R., Castro-Díez P., Maestro-Martínez M., Montserrat-Martí G. 2005. Relationships between phenology and the remobilization of nitrogen, phosphorus and potassium in branches of eight Mediterranean evergreens. New Phytologist 168: 167-178. http://dx.doi.org/10.1111/j.14698137.2005.01477.x

Miyaké K. 1902. On the starch of evergreen leaves and its relation to photosynthesis during the winter. Botanical Gazette 33: 321-340. http://dx.doi. org/10.1086/328232

Miyazawa S., Satomi S., Terashima I. 1998. Slow leaf development of evergreen broad-leaved tree species in Japanese warm temperate forests. Annals of Botany 82: 859-869. http://dx.doi.org/10.1006/ anbo.1998.0770

Miyazawa Y., Kikuzawa K. 2005a. Physiological basis of seasonal trend in leaf photosynthesis of five evergreen broad-leaves species in a temperate deciduous forest. Tree Physiology 26: 249-256. http://dx.doi.org/10.1093/treephys/26.2.249

Miyazawa Y., Kikuzawa K. 2005b. Winter photosynthesis by saplings of evergreen broad-leaved trees in a deciduous temperate forest. New Phytologist 165: 857-866. http://dx.doi.org/10.1111/j.14698137.2004.01265.x

Miyazawa Y., Kikuzawa K., Otsuki K. 2007. Decrease in the capacity for RuBP carboxylation and regeneration with the progression of cold-induced photoinhibition during winter in evergreen broadleaf tree species in a temperate forest. Functional Plant Biology 34: 393-401. http://dx.doi.org/10.1071/ FP06312

Monk C.D. 1966. An ecological significance of evergreenness. Ecology 47: 504-505. http://dx.doi. org/10.2307/1932995

Muller O., Hirose T., Werger M.J.A., Hikosaka K. 2011. Optimal use of leaf nitrogen explains seasonal changes in leaf nitrogen content of an understorey evergreen shrub. Annals of Botany 108: 529-536. http://dx.doi.org/10.1093/aob/mcr167
Muller O., Oguchi R., Hirose T., Werger M.J.A., Hikosaka K. 2009. The leaf anatomy of a broadleaved evergreen allows an increase in leaf nitrogen content in winter. Physiologia Plantarum 136: 299-309. http://dx.doi.org/10.1111/j.13993054.2009.01224.x

Nardini A. 2001. Are sclerophylls and malacophylls hydraulically different? Biologia Plantarum 44: 239-245. http://dx.doi. org/10.1023/A:1010251425995

Nardini A., Salleo S. 2000. Limitation of stomatal conductance by hydraulic traits: sensing or preventing xylem cavitation? Trees 15: 14-24. http:// dx.doi.org/10.1007/s004680000071

Nardini A., Tyree M., Salleo S. 2001. Xylem cavitation in the leaf of Prunus laurocerasus and its impact on leaf hydraulics. Plant Physiology 125: 1700-1709. http://dx.doi.org/10.1104/pp.125.4.1700

Neuner G., Ambach D., Aichner K. 1999. Impact of snow cover on photoinhibition and winter desiccation in evergreen Rhododendron ferrugineum leaves during subalpine winter. Tree Physiology 19: 725-732. http://dx.doi.org/10.1093/treephys/19.11.725

Neuner G., Bannister P. 1995. Frost resistance and susceptibility to ice formation during natural hardening in relation to leaf anatomy in three evergreen tree species from New Zealand. Tree Physiology 15: 371-377. http://dx.doi.org/10.1093/ treephys/15.6.371

Niinemets Ü. 2007. Photosynthesis and resource distribution through plant canopies. Plant, Cell and Environment 30: 1052-1071. http://dx.doi. org/10.1111/j.1365-3040.2007.01683.x

Niinemets Ü., Cescatti A., Rodeghiero M., Tosens T. 2005. Leaf internal diffusion conductance limits photosynthesis more strongly in older leaves of Mediterranean evergreen broadleaved species. Plant, Cell and Environment 28: 1552-1566. http://dx.doi.org/10.1111/j.13653040.2005.01392.x

Niinemets Ü., Cescatti A., Rodeghiero M., Tosens T. 2006. Complex adjustments of photosynthetic potentials and internal diffusion conductance to current and previous light availabilities and leaf age in Mediterranean evergreen species Quercus ilex. Plant, Cell and Environment 29: 1159-1178. http://dx.doi.org/10.1111/j.13653040.2006.01499.x

Niinemets Ü., Díaz-Espejo A., Flexas J., Galmés J., Warren C.R. 2009a. Role of mesophyll diffusion conductance in constraining potential photosynthetic productivity in the field. Journal of Experimental Botany 60: 2249-2270. http://dx.doi. org/10.1093/jxb/erp036

Niinemets Ü., Wright I.J., Evans J.R. 2009b. Leaf mesophyll diffusion conductance in 35 Australi- 
an sclerophylls covering a broad range of foliage structural and physiological variation. Journal of Experimental Botany 60: 2433-2449. http://dx. doi.org/10.1093/jxb/erp045

Nilsen E.T. 1986. Quantitative phenology and leaf survivorship of Rhododendron maximum in contrasting irradiance environments of the southern Appalachian mountains. American Journal of Botany 73: 822-831. http://dx.doi.org/10.2307/2444293

Nilsen E.T. 1992. Thermonastic leaf movements: a synthesis of research with Rhododendron. Botanical Journal of The Linnean Society 110: 205-233. http://dx.doi.org/10.1111/j.1095-8339.1992. tb00291.x

Oberhuber W., Bauer H. 1991. Photoinhibition of photosynthesis under natural conditions in ivy (Hedera helix L.) growing in an understory of deciduous trees. Planta 185: 545-553. http://dx. doi.org/10.1007/BF00202965

Oleksyn J., Reich P.B., Zytkowiak R., Karolewski P., Tjoelker M.G. 2003. Nutrient conservation increases with latitude of origin in European Pinus sylvestris populations. Oecologia 136: 220-235. http://dx.doi.org/10.1007/s00442-003-1265-9

Oliveira G., Peñuelas J. 2002. Comparative protective strategies of Cistus albidus and Quercus ilex facing photoinhibitory winter conditions. Environmental and Experimental Botany 47: 281-289. http:// dx.doi.org/10.1016/S0098-8472(02)00003-5

van Ommen Kloeke A.E.E., Douma J.C., Ordoñez J.C., Reich P.B., van Bodegom P.M. 2012. Global quantification of contrasting leaf life span strategies for deciduous and evergreen species in response to environmental conditions. Global Ecology and Biogeography 21: 224-235. http://dx.doi. org/10.1111/j.1466-8238.2011.00667.x

Ono K., Nishi Y., Watanabe A., Terashima I. 2001. Possible mechanisms of adaptive leaf senescence. Plant Biology 3: 234-243. http://dx.doi. org/10.1055/s-2001-15201

Onoda Y., Richards L., Westoby M. 2012. The importance of leaf cuticle for carbon economy and mechanical strength. New Phytologist 196: 441-447. http://dx.doi.org/10.1111/j.14698137.2012.04263.x

Onoda Y., Westoby M., Adler P.B., Choong A.M.F., Clissold F.J., Cornelissen J.H.C., Díaz S., Dominy N.J., Elgart A., Enrico L., Fine P.V.A., Howard J.J., Jalili A., Kitajima K., Kurokawa H., McArthur C., Lucas P. W., Markesteijn L., Pérez-Harguindeguy N., Poorter L., Richards L., Santiago L.S., Sosinski Jr E.E., van Bael S.A., Warton D.I., Wright I.J., Wright S.J., Yamashita N. 2011. Global patterns of leaf mechanical properties. Ecology Letters 14: 301-312. http://dx.doi.org/10.1111/j.14610248.2010.01582.x
Öquist G., Huner N.P.A. 2003. Photosynthesis of overwintering evergreen plants. Annual Review of Plant Biology 54: 329-355. http://dx.doi. org/10.1146/annurev.arplant.54.072402.115741

Palacio S., Millard P., Maestro M., Montserat-Martí G. 2007. Non-structural carbohydrates and nitrogen dynamics in Mediterranean sub-shrubs: an analysis of the functional role of overwintering leaves. Plant Biology 9: 49-58. http://dx.doi. org/10.1055/s-2006-924224

Pantin F., Simonneau T., Muller B. 2012. Coming of leaf age: control of growth by hydraulics and metabolics during leaf ontogeny. New Phytologist 196: 349-366. http://dx.doi.org/10.1111/j.14698137.2012.04273.x

Pasche F., Pornon A., Lamaze T. 2002. Do mature leaves provide a net source of nitrogen supporting shoot growth in Rhododendron ferrugineum? New Phytologist 154: 99-105. http://dx.doi. org/10.1046/j.1469-8137.2002.00370.x

Peng Y., Arora R., Li G., Wang X., Fessehaie A. 2008a. Rhododendron catawbiense plasma membrane intrinsic proteins are aquaporins, and their over-expression compromises constitutive freezing tolerance and cold acclimation ability of transgenic Arabidopsis plants. Plant, Cell and Environment 31: 1275-1289. http://dx.doi.org/10.1111/ j.1365-3040.2008.01840.x

Peng Y., Lin W., Wei H., Krebs S.L., Arora R. 2008b. Phylogenetic analysis and seasonal cold acclimation-associated expression of early light-induced protein genes of Rhododendron catawbiense. Physiologia Plantarum 132: 44-52.

Piwczyński M., Ponikierska A., Puchałka R., Corral J.M. 2013. Expression of anatomical leaf traits in homoploid hybrids between deciduous and evergreen species of Vaccinium. Plant Biology 15: 522-530. http://dx.doi.org/10.1111/j.14388677.2012.00656.x

Poorter H., Niinemets Ü., Poorter L., Wright I.J., Villar R. 2009. Causes and consequences of variation in leaf mass per area (LMA): a meta analysis. New Phytologist 182: 565-588. http://dx.doi. org/10.1111/j.1469-8137.2009.02830.x

Pornon A., Lamaze T. 2007. Nitrogen resorption and photosynthetic activity over leaf life span in an evergreen shrub, Rhododendron ferrugineum, in a subalpine environment. New Phytologist 175: 301-310. http://dx.doi.org/10.1111/j.14698137.2007.02101.x

Pratt R.B., Ewers F.W., Lawson M.C., Jacobsen A.L., Brediger M.M., Davis S.D. 2005. Mechanisms for tolerating freeze-thaw stress of two evergreen chaparral species: Rhus ovata and Malosma laurina (Anacardiaceae). American Journal of Botany 92: 1102-1113. http://dx.doi.org/10.3732/ ajb.92.7.1102 
Rajashekar C.B., Burke M. J. 1996. Freezing characteristics of rigid plant tissues. Development of cell tension during extracellular freezing. Plant Physiology 111 : 597-603.

Read J., Sanson G.D. 2003. Characterizing sclerophylly: the mechanical properties of a diverse range of leaf types. New Phytologist 160: 81-99. http:// dx.doi.org/10.1046/j.1469-8137.2003.00855.x

Reader R.J. 1978. Contribution of overwintering leaves to the growth of three broad-leaved, evergreen shrubs belonging to the Ericaceae family. Canadian Journal of Botany 56: 1248-1261. http://dx.doi.org/10.1139/b78-139

Reich P.B., Walters M.B., Ellsworth D.S. 1997. From tropics to tundra: Global convergence in plant functioning. Proceedings of National Academy of Sciences (USA) 94: 13730-13734. http://dx.doi. org/10.1073/pnas.94.25.13730

Reich P.B., Ellsworth D.S., Walters M.B. 1998a. Leaf structure (specific leaf area) modulates photosynthesis-nitrogen relations: evidence from within and across species and functional groups. Functional Ecology 12: 948-958. http://dx.doi. org/10.1046/j.1365-2435.1998.00274.x

Reich P.B., Oleksyn J., Modrzyński J., Tjoelker M.G. 1996. Evidence that longer needle retention of spruce and pine populations at high elevations and high latitudes is largely a phenotypic response. Tree Physiology 16: 643-647. http://dx. doi.org/10.1093/treephys/16.7.643

Reich P.B., Rich R.L., Lu X., Wang X., Oleksyn J. 2014. Biogeographic variation in evergreen conifer needle longevity and impacts on boreal forest carbon cycle projections. Proceedings of the National Academy of Sciences of the United States of America (accepted, Oct 23'2013).

Reich P.B., Walters M.B., Ellsworth D.S. 1992. Leaf life-span in relation to leaf, plant, and stand characteristics among diverse ecosystems. Ecological Monographs 62: 365-392. http://dx.doi. org/10.2307/2937116

Reich P.B., Walters M.B., Ellsworth D.S., Vose J.M., Volin J.C., Gresham C., Bowman W.D. 1998b. Relationships of leaf dark respiration to leaf nitrogen, specific leaf area and leaf life-span: a test across biomes and functional groups. Oecologia 114: 471-482. http://dx.doi.org/10.1007/ s004420050471

Reich P.B., Wright I.J., Cavender-Bares J., Craine J.M., Oleksyn J., Westoby M., Walters M.B. 2003. The evolution of plant functional variation: traits, spectra, and strategies. International Journal of Plant Sciences 164(3 Suppl.): S143-S164. http:// dx.doi.org/10.1086/374368

Reyes-Díaz M., Alberdi M., Piper F., Bravo L.A., Corcuera L.J. 2005. Low temperature responses of Nothofagus dombeyi and Nothofagus nitida, two evergreen species from south central Chile. Tree Physiology 25: 1389-1398. http://dx.doi. org/10.1093/treephys/25.11.1389

Rodríguez-Calcerrada J., Limousin J.-M., Martin-StPaul N.K., Jaeger C., Rambal S. 2012. Gas exchange and leaf aging in an evergreen oak: causes and consequences for leaf carbon balance and canopy respiration. Tree Physiology 32: 464-477. http://dx.doi.org/10.1093/treephys/tps020

Roth-Nebelsick A., Uhl D., Mosbrugger V., Kerp H. 2001. Evolution and function of leaf venation architecture: a review. Annals of Botany 87: 553566. http://dx.doi.org/10.1006/anbo.2001.1391

Rotondi A., Rossi F., Asunis C., Cesaraccio C. 2003. Leaf xeromorphic adaptations of some plants of a coastal Mediterranean macchia ecosystem. Journal of Mediterranean Ecology 4: 25-35.

Russell R.B., Lei T.T., Nilsen E.T. 2009. Freezing induced leaf movements and their potential implications to early spring carbon gain: Rhododendron maximum as exemplar. Functional Ecology 23: 463-471. http://dx.doi.org/10.1111/j.13652435.2008.01534.x

Sack L., Frole K. 2006. Leaf structural diversity is related to hydraulic capacity in tropical rain forest trees. Ecology 87: 483-491. http://dx.doi. org/10.1890/05-0710

Sack L., Holbrook M.N. 2006. Leaf hydraulics. Annual Review of Plant Biology 57: 361381. http://dx.doi.org/10.1146/annurev.arplant.56.032604.144141

Sakai A., Larcher W. 1987. Frost survival of plants. Responses and adaptation to freezing stress. Ecological Studies 62. Springer, Berlin, $321 \mathrm{p}$.

Salleo S., Lo Gullo M.A. 1990. Sclerophylly and plant water relations in three Mediterranean Quercus species. Annals of Botany 65: 259-270.

Salleo S., Lo Gullo M.A., Raimondo F., Nardini A. 2001. Vulnerability to cavitation of leaf minor veins: any impact on leaf gas exchange? Plant, Cell and Environment 24: 851-859. http://dx. doi.org/10.1046/j.0016-8025.2001.00734.x

Salleo S., Nardini A., Lo Gullo M.A. 1997. Is sclerophylly of Mediterranean evergreens an adaptation to drought? New Phytologist 135: 603-612. http:// dx.doi.org/10.1046/j.1469-8137.1997.00696.x

Salleo S., Raimondo F., Trifiló P., Nardini A. 2003. Axial-to-radial water permeability of leaf major veins: a possible determinant of the impact of vein embolism on leaf hydraulics. Plant, Cell and Environment 26: 1749-1758. http://dx.doi. org/10.1046/j.1365-3040.2003.01092.x

Sefton C.A., Montagu K., Atwell B.J., Conroy J.P. 2002. Anatomical variation in juvenile eucalypt leaves accounts for differences in specific leaf area and $\mathrm{CO}_{2}$ assimilation rates. Australian Journal of 
Botany 50: 301-310. http://dx.doi.org/10.1071/ BT01059

Simonin K.A., Limm E.B., Dawson T.E. 2012. Hydraulic conductance of leaves correlates with leaf lifespan: implications for lifetime carbon gain. New Phytologist 193: 939-947. http://dx.doi. org/10.1111/j.1469-8137.2011.04014.x

Sobrado M.A. 1986. Aspects of tissue water relations and seasonal changes of leaf water potential components of evergreen and deciduous species coexisting in tropical dry forests. Oecologia 68: 413416. http://dx.doi.org/10.1007/BF01036748

Starr G., Oberbauer S.F. 2003. Photosynthesis of Arctic evergreens under snow: implications for tundra ecosystem carbon balance. Ecology 84: 1415-1420. http://dx.doi.org/10.1890/02-3154

Syvertsen J. P., Lloyd J., McConchie C., Kriedemann P.E., Farquhar G.D. 1995. On the relationship between leaf anatomy and $\mathrm{CO}_{2}$ diffusion through the mesophyll of hypostomatous leaves. Plant, Cell and Environment 18: 149-157. http://dx. doi.org/10.1111/j.1365-3040.1995.tb00348.x

Takashima T., Hikosaka K., Hirose T. 2004. Photosynthesis or persistence: nitrogen allocation in leaves of evergreen and deciduous Quercus species. Plant, Cell and Environment 27: 1047-1054. http://dx. doi.org/10.1111/j.1365-3040.2004.01209.x

Taneda H., Tateno M. 2005. Hydraulic conductivity, photosynthesis and leaf water balance in six evergreen woody species from fall to winter. Tree Physiology 25: 299-306. http://dx.doi.org/10.1093/ treephys/25.3.299

Tattini M., Remorini D., Pineli P., Agati G., Saracini E., Traversi M.L., Massai R. 2006. Morpho-anatomical, physiological and biochemical adjustments in response to root zone salinity stress and high solar radiation in two Mediterranean evergreen shrubs, Myrtus communis and Pistacia lentiscus. New Phytologist 170: 779-794. http:// dx.doi.org/10.1111/j.1469-8137.2006.01723.x

Terashima I., Hanba Y.T., Tazoe Y., Vyas P., Yano S. 2006. Irradiance and phenotype: comparative eco-development of sun and shade leaves in relation to photosynthetic $\mathrm{CO}_{2}$ diffusion. Journal of Experimental Botany 57: 343-354. http://dx.doi. org/10.1093/jxb/erj014

Terashima I., Hanba Y.T., Tholen D., Niinemets Ü. 2011. Leaf functional anatomy in relation to photosynthesis. Plant Physiology 155: 108-116. http://dx.doi.org/10.1104/pp.110.165472

Terashima I., Hikosaka K. 1995. Comparative ecophysiology of canopy and leaf photosynthesis. Plant, Cell and Environment 18: 1111-1128. http://dx.doi.org/10.1111/j.1365-3040.1995. tb00623.x

Terashima I., Ishibashi M., Ono K., Hikosaka K. 1995. Three resistances to $\mathrm{CO}_{2}$ diffusion: leaf-surface water, intercellular spaces and mesophyll cells. In: Photosynthesis: from Light to Biosphere, Vol. V. Mathis P. (ed.) Kluwer Academic Press, Dordrecht, pp. 537-542.

Tjoelker M.G., Reich P.B., Oleksyn J. 1999. Changes in leaf nitrogen and carbohydrates underlie temperature and $\mathrm{CO}_{2}$ acclimation of dark respiration in five boreal tree species. Plant, Cell and Environment 22: 767-778. http://dx.doi.org/10.1046/ j.1365-3040.1999.00435.x

Tomás M., Flexas J., Copolovici L., Galmés J., Hallik L., Medrano H., Ribas-Carbó M., Tosens T., Vislap V., Niinemets Ü. 2013. Importance of leaf anatomy in determining mesophyll diffusion conductance to $\mathrm{CO}_{2}$ across species: quantitative limitations and scaling up by models. Journal of Experimental Botany 64: 2269-2281. http://dx.doi. org/10.1093/jxb/ert086

Tosens T., Niinemets Ü., Westoby M., Wright J.J. 2012. Anatomical basis of variation in mesophyll resistance in eastern Australian sclerophylls: news of a long and winding path. Journal of Experimental Botany 63: 5105-5119. http://dx.doi. org/10.1093/jxb/ers171

Turner I.M. 1994. Sclerophylly: primarily protective? Functional Ecology 8: 669-675. http://dx.doi. org/10.2307/2390225

Tyree M.T., Sperry J.S. 1989. Vulnerability of xylem to cavitation and embolism. Annual Review of Plant Physiology and Molecular Biology 40: 19-38. http://dx.doi.org/10.1146/annurev. pp.40.060189.000315

Valladares F., Arrieta S., Aranda I., Lorenzo D., Sánchez-Gómez D., Tena D., Suárez F., Pardos J.A. 2005. Shade tolerance, photoinhibition sensitivity and phenotypic plasticity of Ilex aquifolium in continental Mediterranean sites. Tree Physiology 25: 1041-1052. http://dx.doi.org/10.1093/treephys/25.8.1041

Valladares F., Wright S.J., Lasso E., Kitajima K., Pearcy R.W. 2000. Plastic phenotypic response to light of 16 congeneric shrubs from a Panamanian rainforest. Ecology 81: 1925-1936. http://dx.doi. org/10.1890/0012-9658(2000)081 [1925:PPRTLO]2.0.CO;2

Varone L., Gratani L. 2007. Physiological response of eight Mediterranean maquis species to low air temperatures during winter. Photosynthetica 45: 385-391. http://dx.doi.org/10.1007/s11099007-0065-6

Verhoeven A.S., Adams W.W. III, Demmig-Adams B. 1998. Two forms of sustained xanthophyll cycle-dependent energy dissipation in overwintering Euonymus kiautschovicus. Plant, Cell and Environment 21: 893-903. http://dx.doi.org/10.1046/ j.1365-3040.1998.00338.x 
Villar R., Held A.A., Merino J. 1995. Dark leaf respiration in light and darkness of an evergreen and a deciduous plant species. Plant Physiology 107: 421-427.

Villar R., Merino J. 2001. Comparison of leaf construction costs in woody species with differing leaf life-spans in contrasting ecosystems. New Phytologist 151: 213-226. http://dx.doi.org/10.1046/ j.1469-8137.2001.00147.x

Villar R., Robleto J.R., De Jong Y., Poorter H. 2006. Differences in construction costs and chemical composition between deciduous and evergreen woody species are small as compared to differences among families. Plant, Cell and Environment 29: 1629-1643. http://dx.doi.org/10.1111/j.13653040.2006.01540.x

Villar R., Ruiz-Robleto J., Ubera J.R., Poorter H. 2013. Exploring variation in leaf mass per area (LMA) from leaf to cell: An anatomical analysis of 26 woody species. American Journal of Botany 100: 1969-1980. http://dx.doi.org/10.3732/ ajb.1200562

Vogelmann T.C. 1993. Plant tissue optics. Annual Review of Plant Physiology and Plant Molecular Biology 44: 231-251. http://dx.doi.org/10.1146/ annurev.pp.44.060193.001311

Walters M.B., Reich P.B. 1999. Low-light carbon balance and shade tolerance in the seedlings of woody plants: do winter deciduous and broadleaved evergreen species differ? New Phytologist 143: 143-154. http://dx.doi.org/10.1046/j.14698137.1999.00425.x

Wang X., Arora R., Horner H.T., Krebs S.L. 2008. Structural adaptations in overwintering leaves of thermonastic and nonthermonastic Rhododendron species. Journal of the American Society for Horticultural Science 133: 768-776.

Warren C.R., Adams M.A. 2004. Evergreen trees do not maximize instantaneous photosynthesis. Trends in Plant Science 9: 270-274. http://dx.doi. org/10.1016/j.tplants.2004.04.004

Warren C.R., Adams M.A., Chen ZL. 2000. Is photosynthesis related to concentrations of nitrogen and Rubisco in leaves of Australian native plants? Australian Journal of Plant Physiology 27: 407416.

Wisniewski M., Gusta L., Neuner G. 2014. Adaptive mechanisms of freeze avoidance in plants: A brief update. Environmental and Experimental Botany 99: 133-140. http://dx.doi.org/10.1016/j.envexpbot.2013.11.011

Witkowski E.T.F., Lamont B.B. 1991. Leaf specific mass confounds leaf density and thickness. Oecologia 88: 486-493.

Wright I.J., Cannon K. 2001. Relationships between leaf lifespan and structural defences in a low-nutrient, sclerophyll flora. Functional Ecology 15:
351-359. http://dx.doi.org/10.1046/j.13652435.2001.00522.x

Wright I.J., Leishman M.R., Read C., Westoby M. 2006. Gradients of light availability and leaf traits with leaf age and canopy position in 28 Australian shrubs and trees. Functional Plant Biology 33: 407-419. http://dx.doi.org/10.1071/FP05319

Wright I.J., Reich P.B., Cornelissen J.H.C., Falser D.S., Garnier E., Hikosaka K., Lamont B.B., Lee W., Oleksyn J., Osada N., Poorter H., Villar R., Warton D.I., Westoby M. 2005a. Assessing the generality of global leaf trait relationships. New Phytologist 166: 485-496. http://dx.doi.org/10.1111/j.14698137.2005.01349.x

Wright I.J., Reich P.B., Cornelissen J.H.C., Falser D.S., Groom P.K., Hikosaka K., Lee W., Lusk C.H., Niinemets Ü., Oleksyn J., Osada N., Poorter H., Warton, D.I., Westoby M. 2005b. Modulation of leaf economic traits and trait relationships by climate. Global Ecology and Biogeography 14: 411-421. http://dx.doi.org/10.1111/j.1466822x.2005.00172.x

Wright I.J., Reich P.B., Westoby M., Ackerly D.D., Baruch Z., Bongers F., Cavender-Bares J., Chapin T., Cornelissen J.H.C., Diemer M., Flexas J., Garnier E., Groom P.K., Gulias J., Hikosaka K., Lamont B.B., Lee T., Lee W., Lusk C., Midgley J.J., Navas M.-L., Niinemets Ü., Oleksyn J., Osada N., Poorter H., Poot P., Prior L., Pyankov V.I., Roumet C., Thomas S.C., Tjoelker M.G., Veneklaas E.J., Villar R. 2004. The worldwide leaf economic spectrum. Nature 428: 821-827. http://dx.doi.org/10.1038/ nature02403

Wright I.J., Westoby M., Reich P.B. 2002. Convergence towards higher leaf mass per area in dry and nutrient-poor habitats has different consequences for leaf life span. Journal of Ecology 90: 534-543. http://dx.doi.org/10.1046/j.13652745.2002.00689.x

Xu C.-Y., Griffin K.L., Schuster W.S.F. 2007. Leaf phenology and seasonal variation of photosynthesis of invasive Berberis thunbergii (Japanese barberry) and two co-occurring native understory shrubs in a northeastern United States deciduous forest. Oecologia 154: 11-21. http://dx.doi. org/10.1007/s00442-007-0807-y

Yasumura Y., Ishida A. 2010. Temporal variation in leaf nitrogen partitioning of a broad-leaved evergreen tree, Quercus myrsinaefolia. Journal of Plant Research 124: 115-123. http://dx.doi. org/10.1007/s10265-010-0358-x

Zanne A.E., Tank D.C., Cornwell W.K., Eastman J.M., Smith S.A., FitzJohn R.G., McGlinn D.J., O'Meara B.C., Moles A.T., Reich P.B., Royer D.L., Soltis D.E., Stevens P.F., Westoby M., Wright I.J., Aarssen L., Bertin R.I., Calaminus A., Govaerts R., Hemmings F., Leishman M.R., Oleksyn J., Sol- 
tis P.S., Swenson N.G., Warman L., Beaulieu J.M. 2014. Three keys to the radiation of angiosperms into freezing environments. Nature 506: 89-92. http://dx.doi.org/10.1038/nature12872

Zarter C.R., Adams W.W. III, Ebbert V., Adamska I., Jansson S., Demmig-Adams B. 2006. Winter acclimation of PsbS and related proteins in the evergreen Arctostaphylos uva-ursi as influenced by altitude and light environment. Plant, Cell and Environment 29: 869-878. http://dx.doi. org/10.1111/j.1365-3040.2005.01466.x

Zimmermann M.H. 1983. Xylem structure and the ascent of sap. Springer, Berlin, 143 p. http://dx. doi.org/10.1007/978-3-662-22627-8

Zwieniecki M.A., Brodribb T.J., Holbrook N.M. 2007. Hydraulic design of leaves: insights from rehydration kinetics. Plant, Cell and Environment 30: 910-921. http://dx.doi.org/10.1111/j.13653040.2007.001681.x 